\title{
Materiales didácticos para el desarrollo de la competencia intercultural en el aula de español como L2 en niños hablantes de namtrik
}

\author{
Mónica Chamorro Mejía
}

Universidad del Valle (Cali, Colombia)

RESUMEN: Los materiales que se presentan a continuación son el resultado de una investigación acerca de las dificultades de aprendizaje del español como segunda lengua de niños hablantes de namtrik, una lengua indígena actualmente hablada en el suroccidente de Colombia. Los niños, en el momento en el que se realizó este estudio, estaban matriculados en el quinto año de educación primaria en la Institución Educativa Misak Mamá Manuela, una escuela bilingüe que pertenece a la red educativa de la comunidad indígena misak, ubicada en el interior del Resguardo de Guambía. Para contextualizar los materiales, se describe, en primer lugar, la situación actual de la escuela indígena bilingüe colombiana dentro de la perspectiva de lo que han sido las políticas lingüísticas del Estado colombiano a lo largo de su historia republicana; en segundo lugar, se detallan las características del pueblo misak; y, en tercer lugar, se presenta la explicación de la propuesta didáctica, constituida por cuatro secuencias de actividades centradas en el desarrollo de la competencia intercultural.

PALABRAS CLAVE: Lenguas indígenas, hablantes de namtrik, competencia intercultural, materiales didácticos, español L2, educación primaria.

\section{Didactic materials for the development of intercultural competence in the Spanish as L2} classroom for Namtrik-speaking children.

ABSTRACT: The materials presented below are the result of a research project about the difficulties in learning Spanish experienced by children who speak Namtrik, an indigenous language currently spoken in southwestern Colombia, as their mother tongue. At the time of the study, the children were enrolled in the fifth year of Primary School at the Misak Mamá Manuela Educational Institution, a bilingual school belonging to the educational network of the Misak indigenous community, located inside the Resguardo de Guambía. In order to contextualise the materials, firstly, the current situation of the Colombian indigenous bilingual school is described within the perspective of the linguistic policies of the Colombian State throughout its republican history; secondly, the characteristics of the Misak people are detailed; and thirdly, the didactic proposal, consisting of four sequences of activities aimed at developing the intercultural competence, is presented.

KEYWORDS: Indigenous languages, namtrik speakers, intercultural competence, didactic materials, Spanish L2, primary education.

Chamorro Mejía, M. (2021): "Materiales didácticos para el desarrollo de la competencia intercultural en el aula del español como L2 en niños hablantes de namtrik", Revista de Recursos para el Aula de Español: investigación y enseñanza, 1, 95-150. https://doi.org/10.37536/rr.1.1.2021.1502 


\section{Introducción}

Colombia es un país que tiene una gran variedad étnica y lingüística en su territorio: según los estudios de Landaburu (2005) existen alrededor de 65 lenguas indígenas y 2 patois. Esta diversidad se debe a las características geográficas, tanto en su posición en el subcontinente como a su relieve y orografía, que segmentan el país en áreas relativamente aisladas e independientes. Pese a esta pluralidad etnolingüística de facto, ya desde el primer momento de la constitución de Colombia como un Estado nación, las políticas lingüísticas han buscado minimizar la heterogeneidad y reconducir la pluralidad a un monolingüismo hispanizante que anula la diversidad. Después de las guerras de independencia (Liévano 1966) la minoría racial de origen europeo en el poder centró su proyecto de nación en la consolidación de una identidad que hiciera referencia a los valores de la civilización occidental, entendida como una oposición a la barbarie representada por los pueblos originarios o no occidentales (López 2001). En esta medida, el sistema educativo se organizó institucionalmente alrededor de la idea de reconducir a la población indígena, negra y mestiza al monolingüismo hispánico (Rojas y Castillo 2004), entendido como un mecanismo homogeneizador y civilizador capaz de extirpar lo no blanco, considerado como una mancha o un desperfecto de la organización social. Las lenguas indígenas se excluyeron de la identidad nacional y se proscribieron en el sistema educativo y en los ámbitos públicos. La estructura educativa responde a estos principios, que alcanzan su mayor vigor al finalizar el siglo XIX con la firma del Concordato con el Vaticano y con la firma de la primera Convención con las Misiones Católicas en 1888, quienes se encargarían específicamente de la colonización y cristianización de la periferia. Este concepto de periferia se relaciona con las poblaciones indígenas, concebidas como un componente salvaje. Los pueblos salvajes a su vez se definían como aquellos que hablaban en lenguas aborígenes, no habían sido bautizados y desconocían las costumbres de la sociedad católica. El decreto 491 de 1904 (como se citó en Bodnar 1990) prioriza la educación de las tribus salvajes, en particular la de los niños. La enseñanza del español es esencial en este proceso de aculturación y se considera el medio idóneo para extirpar la barbarie indígena. La educación se llevó a cabo mediante la modalidad de internado; en este sentido el niño indígena abandonaba su ambiente nativo y era sometido a una inmersión plena en la cultura dominante. En este contexto le estaba prohibido hablar su propia lengua (Bodnar 1990).

Solo a finales del siglo XX se derogó el monolingüismo y se reconoció la existencia de otras variedades lingüísticas. Estas nuevas políticas, que significaron una trabajosa ruptura 
con el pasado, pueden considerarse el resultado de un largo y difícil proceso que se inició a principios del siglo XX con la llegada de las ideas socialistas, retomadas en un principio por el partido liberal y después por los movimientos de izquierdas y por las guerrillas revolucionarias. Este conflicto social, con un saldo de varios millones de muertos y que aún hoy no termina de resolverse, permitió que se gestara y concretara una transformación de las políticas lingüísticas, hasta ese momento concentradas en el rechazo de las demás lenguas colombianas.

La primera disposición legal que favorece un nuevo modelo etnoeducativo data de 1974 y en 1978 se crea el primer programa de educación bilingüe y ese mismo año se expide el decreto 1142 en el que se usa por primera vez el término educación indígena en el sistema jurídico colombiano. Este decreto autoriza la autonomía en el diseño curricular e insiste en la introducción de la educación en lengua indígena y español como L2; además, reconoce el derecho de la comunidad a elegir y sostener sus propios maestros (García 1999). A principios de los años ochenta y durante los años noventa se expiden una serie de decretos fundamentales en el ámbito etnoeducativo como el Decreto 85 de 1980, bilingüismo del maestro indígena, y la Resolución 3454 de 1986 en el que se crea el Programa Nacional de Etnoeducación. Finalmente, en 1991 se realiza la consagración constitucional definitiva de principios como la multiculturalidad y el bilingüismo (República de Colombia, 1991, Art.10). Una vez oficializadas las normas que reconocen constitucionalmente la interculturalidad, las comunidades empezaron a poner en práctica sus propios proyectos educativos que hasta ese momento habían estado sujetos a la clandestinidad e incluso a la ilegalidad. Podemos considerar que los aspectos apenas reseñados son los directos antecedentes de la constitución de un movimiento pedagógico propiamente étnico.

Es importante señalar que la instauración de este modelo educativo encontró resistencia, durante este primer momento, no solo en el ámbito de las instituciones tradicionales, sino también en el contexto de las comunidades mismas, que en muchas ocasiones no lograban entronizar el sentido de una educación que partiera de los propios valores y de la lengua tradicional. La escolarización era percibida por el indígena como una apropiación de la cultura ajena y no como un espacio de difusión de la propia cultura. El aprendizaje del español se concebía como una herramienta para que los jóvenes se integraran a las dinámicas productivas del modelo occidental y la lengua indígena se confinaba al espacio doméstico. 
Gracias a los esfuerzos de las organizaciones indígenas durante las últimas dos décadas del siglo XX, se superaron en mayor o menor grado estas dificultades iniciales, de suerte que la educación bilingüe de la escuela indígena hoy en día se concibe no solo como un modelo de educación lingüística sino también como un proceso de descolonización y de reapropiación de los valores culturales (Trillos 1999).

\section{El pueblo misak}

Los indígenas colombianos misak están ubicados en la vertiente occidental de la cordillera Central y sus tierras tienen altitudes que van desde los 2500 a los 3800 metros sobre el nivel del mar. La temperatura oscila entre 5 y 14 grados centígrados (Cabildo Indígena de Guambía [CIG] 1994). El 70\% del área del territorio tiene pendientes superiores al 60\%; es decir que presenta un relieve fuertemente quebrado, razón que implica serias limitaciones en el uso de los suelos. El pueblo misak, aunque no es particularmente numeroso ${ }^{45}$ en el contexto de la población indígena colombiana, sobresale por su gran identidad cultural. Pese a permanecer durante más de cuatro siglos en estrecho contacto con la civilización occidental (el Resguardo de Guambía ${ }^{46}$, territorio en el que habitan la mayor parte de los misak, está a pocos kilómetros de centros urbanos de importancia como Cali o Popayán) conservan su lengua, su vestuario, su espiritualidad y en general sus tradiciones. Son un pueblo que centra su vida social en el trabajo comunitario y en el respeto por las autoridades tradicionales. La familia es el centro de la vida misak y dentro del territorio del Resguardo existen familias de dos tipos: la familia nuclear, en la que conviven los padres con sus hijos, y la familia extensa, constituida por agnados y afines. Practican la monogamia y su estructura de autoridad es patriarcal (CIG 2005).

Los misak se consideran piurek o hijos del agua. Uno de los tantos mitos dice que de dos lagunas, Nupisu o Piendamó (laguna macho) y Ñimbe (laguna mujer), nació la pareja inicial. En este sitio también habita el pishimisak (que es él y ella, masculino y femenino), que significa tranquilidad, equilibrio y armonía. Entre los mayores o ancianos existe una leyenda de "una época de grandes derrumbes, que arrastraban gigantescas piedras dejando grandes heridas en las montañas. De ellos salieron los humanos que eran la raíz de los nativos" (CIG 2005). Al derrumbe le dicen pikuk que significa "parir el agua" (CIG 2005). Los pishau (primeros

\footnotetext{
${ }^{45}$ Según el último censo del DANE (2019) para el 2018, 21.713 personas se autodefinen como misak.

${ }^{46}$ Resguardo es el nombre con el que la institucionalidad colombiana denomina a los territorios indígenas que cuentan con autonomía política y legislativa.
} 
hombres) eran gigantes muy sabios que comían y se alimentaban de los elementos de la naturaleza y que no eran bautizados (CIG 2005).

La concepción del tiempo es importante para entender el pensamiento misak y es una de las bases más significativas para comprender por qué se resisten con frecuencia de las dinámicas económicas y culturales occidentales. La idea de pasado es una proyección hacia delante, hacia el futuro. Quienes ya vivieron la experiencia de la vida pueden comprender lo que será en el tiempo (una idea de futuro que no es progresivo). Todo lo que está por hacer se está ya desarrollando en el pasado en el transcurso espiral del tiempo y del espacio; es decir, lo que nosotros llamamos futuro para ellos significa regresar al origen de la vida (ir hacia atrás, regresar al agua) por esta razón la vida en el tiempo y el espacio no es pensada de forma lineal sino en espiral.

El territorio para los misak trasciende del universo material al espiritual, lo denominan derecho mayor: en el territorio se nace, se crece y se desarrolla la identidad y la lengua misak (CIG 2005). Pese a que su mundo espiritual está dominado por la religión católica, existen elementos que conviven en forma sincrética, entre los que cabe mencionar, por su importancia, una piedra llamada del sueño, a través de la cual los médicos tradicionales continúan transmitiendo los conocimientos y la sabiduría del pishimisak. En esta piedra se observan unas espirales con las cuales el pishimisak les enseñó a interpretar el mundo material y espiritual a los hijos del agua.

Para los misak la medicina occidental debe trabajar conjuntamente con la medicina propia, es decir que "las políticas gubernamentales se articulen debidamente a la dinámica de los procesos socioculturales de nuestra comunidad". La educación y capacitación en salud requieren de una formación integral que cubra tres aspectos: mental, corporal y espiritual (CIG 1994). Todo lo anterior explica por qué quien se ocupa de prestar la atención primaria a todo tipo de enfermedades es el médico tradicional. Solamente cuando la enfermedad no cede y el paciente se agrava es cuando se acude a la medicina occidental, a los puestos de salud o al hospital. Es muy común que cuando un indígena está hospitalizado su familia decida renunciar a ciertos procedimientos y/o tratamientos. El médico en la comunidad es una especie de chamán que tiene la capacidad de conectarse con el mundo extrasensorial con el fin de aliviar los dolores, orientar sobre sueños, predecir sobre cultivos y prescribir tratamientos sobre enfermedades en general. 


\subsection{Sistema de producción}

Su sistema de producción expresa una compleja relación entre el hombre misak y el medio ambiente, definida por su sistema de valores relativos a la producción, distribución y consumo de los sectores agrícola, ganadero y pesquero. La forma de explotación de los recursos naturales es el resultado de un largo proceso de observación, conocimiento y convivencia con el territorio y con la trasmisión de sus saberes tradicionales adaptados a la economía del entorno.

La chagra o huerta tradicional se ubica por lo general en terrenos aledaños a la vivienda y es el eje principal de su actividad agrícola; esta huerta se complementó con la tierra recuperada en el proceso de ampliación del Resguardo. La principal actividad económica y de la que derivan su sustento diario es la agricultura; cultivan la cebolla larga, el ajo, la papa y el maíz en mayor proporción, el fríjol, la arveja, la col, el repollo y algunas hortalizas en menor grado. Antiguamente cultivaban la majúa y la oca, tubérculos que han desaparecido casi en su totalidad.

Tanto hombres como mujeres participan de las labores necesarias para llevar el cultivo a buen término. La productividad es muy baja y en la mayoría de los casos produce pérdidas por el alto costo de los insumos. Los únicos cultivos rentables son la cebolla larga y el ajo. La papa o patata produce grandes pérdidas debido a la variación de precios. No se practica la rotación de los cultivos, ni el mejoramiento genético de las semillas. La calidad de la producción no es muy buena y esto disminuye su competitividad con otras zonas productoras. Actualmente han cobrado gran importancia los cultivos de trucha Arco Iris (oncorinchus mykis) y también el cultivo de la amapola; esta flor se cultiva para la extracción del opio y sus derivados, cuyo tráfico está penalizado por la ley colombiana e internacional. A este respecto el Cabildo (máxima autoridad del Resguardo) ha iniciado un programa de sustitución de cultivos ilícitos que lentamente está retornando la agricultura misak al modelo tradicional. Los martes de cada semana, el pueblo misak lleva sus productos al mercado de Silvia, el centro urbano más próximo, y este día constituye el descanso semanal.

La ganadería es otra de las actividades practicada por los misak o guambianos; ser propietario de ganado significa poder y riqueza. Se trata, sin embargo, de una ganadería en pequeña escala, porque sus parcelas son pequeñas y los animales no se reproducen en masa. La ganadería es vacuna y ovina, para extraer carne, leche y lana. 


\subsection{Educación}

Para la comunidad misak, la educación constituye un elemento clave y estratégico para recuperar conocimientos y valores que reconduzca a la comunidad a un reencuentro con su propia identidad. Es una forma de reforzar su identidad cultural y su coherencia social lo que es indispensable para definir su destino histórico y su articulación con la sociedad occidental en términos de paridad. Consideran que la educación se basa en el respeto, en la relación armónica con los otros y con la naturaleza y comprende todos los ámbitos de la vida (CIG 1994).

Durante los primeros años de vida, la madre misak tiene un papel muy importante, pues ella lleva a su hijo cargado en la espalda todo el tiempo, mientras cocina, en el trabajo, cuando camina, en las reuniones. De los tres a los seis años los bebés se entregan a las madres comunitarias quienes cuidan a los niños mientras la madre trabaja, dado que las mujeres misak trabajan la tierra a la par que los hombres. De aquí en adelante el niño ingresa en la escuela más próxima a su vivienda, donde inicia sus estudios de básica primaria. Puede afirmarse que en general el movimiento indígena que propugna por una educación propia ha rendido sus frutos. En Guambía existen, además de la red de escuelas indígenas, comités de educación, de historia, de música, de mitos y leyendas, de artesanías, con la activa participación de los mayores y los taitas (título que reciben todos los gobernadores del Cabildo o quienes se han destacado en diferentes trabajos comunitarios).

\subsection{La lengua namtrik}

La lengua namtrik, también conocida como guambiano, es hablada por la comunidad indígena misak o guambiana. Según Landaburu (2005), el número de hablantes se aproxima a unas 21000 personas, mientras que Vásquez de Ruiz (2000) da una cifra aproximada de 18 000. La mayor parte de los hablantes de namtrik son bilingües y se hallan concentrados en el Resguardo indígena de Guambía; según datos del Ministerio de Cultura Colombiano, un 93\% de la población de este Resguardo se define hablante competente de esta lengua. Entre tanto, los resguardos colindantes de Totoró y Kizgó, en los que también se asentó la población misak, presentan porcentajes comparativamente menores de usuarios competentes: en Totoró, el 67\% de la población no habla namtrik y un 33\% tiene solo competencias parciales (la entiende mas no la habla) o habla únicamente español; en el Resguardo de Kisgó, el 53\% se declara no hablante de esta lengua indígena y un $47 \%$ se declara usuario parcial o hablante exclusivo de castellano.

El namtrik es una lengua aglutinante y flexiva que, según Curnow y Liddicoat (1998) y Landaburu (2005), se incluye dentro de la familia barbacoa, la cual se extiende en el 
suroccidente andino colombiano y en el Ecuador. Otras lenguas de la misma familia son el chachi o cayapa, el tsafiki o colorado y el awa o kwaiquer (Landaburu 2005). Históricamente el namtrik ha sido una lengua de trasmisión oral; sin embargo, actualmente tiene una escritura alfabética a partir del alfabeto latino. Para facilitar los procesos de enseñanza/aprendizaje de la lengua, se ha buscado que la escritura se base estrechamente en la fonología, de suerte que cada fonema sea representado por un solo grafema (Muelas y Triviño 2011).

\section{Materiales didácticos y motivación integrativa}

Los materiales didácticos que aparecen en las páginas sucesivas responden a las dificultades de aprendizaje extrapoladas a partir de los resultados de una investigación constituida por una observación participante y por un estudio de actitudes lingüísticas. En estos estudios se concluyó que existe una contradicción entre motivación relativamente alta y dificultades de aprendizaje de los niños. Los alumnos encuestados consideran que es importante y positivo aprender español y se sienten motivados a involucrar esfuerzos en su adquisición, pero los resultados no corresponden a los objetivos de aprendizaje respecto a diversos niveles de la lengua. Esta aparente contradicción se explica a partir de las percepciones negativas de los aprendientes respecto a dos variables: por una parte, las actitudes lingüísticas negativas hacia la variedad dialectal del español que se propone como modelo (español hablado en la ciudad de Popayán, centro urbano más próximo al Resguardo y escenario de la discriminación de la élite postcolonial hacia los indígenas) y por otra parte, las percepciones negativas hacia el español con marcas de namtrik, hablado por los indígenas. Se podría inferir entonces que la motivación del proceso de aprendizaje se ubicaría en el campo de lo instrumental y no de lo integrativo. Según los hallazgos de Gardner y Lambert (1972), la motivación instrumental hace referencia a fines esencialmente pragmáticos o prácticos relacionados con logros de naturaleza social, entretanto la motivación integrativa se refiere al deseo del aprendiente de identificarse con la cultura de la lengua target pues tiene percepciones positivas de la misma. Asimismo, Gardner (2001) considera que el genuino interés en acercarse a la cultura de la lengua extranjera implica respeto y apertura hacia la identidad cultural de la misma y también una identificación emotiva. Esta apertura emotiva constituye un elemento que Gardner (2001) denomina integración y que junto a las actitudes hacia la situación de aprendizaje (docente, pares, syllabus, materiales, actividades extracurriculares asociadas con el curso, etc.) y la motivación (entendida como la fuerza que guía cada situación de aprendizaje y que incluye los recursos empleados y el placer de aprender) forman el modelo de motivación integrativa, capaz de definir el éxito de un proceso 
de aprendizaje de una lengua extranjera. A partir de estas consideraciones, se orientó el diseño de los materiales hacia el desarrollo de un aspecto integrativo en la motivación del alumnado a través de la adquisición/aprendizaje de la competencia intercultural.

Para efectos de este diseño didáctico se toma en cuenta la definición de Fantini y Tirmizi (2006: 12) de competencia intercultural: “[...] a complex of abilities needed to perform effectively and appropriately when interacting with others who are linguistically and culturally different from oneself". En este concepto, la efectividad y la adecuación son los elementos centrales que permiten concebir esta competencia como la capacidad pragmática de transmitir significados apropiados al contexto. A este respecto, Meyer (como se citó en Oliveras 2000: 38) define la competencia intercultural como "la habilidad de una persona de actuar de forma adecuada y flexible al enfrentarse con acciones, actitudes y expectativas de otras culturas". En este concepto se incluyen además de la adecuación, la flexibilidad, que en este caso hace referencia a la capacidad de adaptarse a las diferencias de los elementos culturales de la lengua madre y de la lengua extranjera.

La competencia intercultural aparece como apropiada para mejorar el componente integrativo de la motivación de los niños de quinto de primaria de la comunidad misak, en tanto les permitirá resolver problemas creados por las distancias culturales en este caso provenientes del largo conflicto histórico de las comunidades de habla en contacto. Una adecuada competencia intercultural permitirá adquirir una mirada crítica hacia las identidades en conflicto a partir de aquello que Oliveras (2000) define como una estabilización de la propia identidad. El hablante podrá involucrarse en un proceso de superación de los estereotipos ligados a las identidades en juego y establecer conexiones que le permitan auténticos intercambios semánticos con la cultura y la lengua target o meta. El diseño didáctico propuesto se orienta entonces al desarrollo de una literacidad entendida como un concepto que se extiende hacia lo sociocultural y, en esta medida, como una competencia múltiple y plurilingüe capaz de potenciar la comunicación intercultural.

Como se puede evidenciar en la tabla introductoria de cada una de las cuatro secuencias, se toma como punto de partida lo que Candelier et al. (2008) definen en el MAREP una macrocompetencia $\mathrm{C} 2$, relacionada con gestionar la comunicación lingüística y cultural en contextos de alteridad. Las microcompetencias que sirven de marco para los objetivos de cada secuencia harán referencia a: la resolución de conflictos, obstáculos y malentendidos, y a las competencias de negociación y mediación (Candelier et al. 2008). La secuencia didáctica número uno, La leyenda del duende, trabaja la literacidad desde un texto narrativo que cuenta la 
historia del duende, una de las leyendas mitológicas de la cultura mestiza. Busca establecer un diálogo intercultural entre la lengua materna y la L2, que ponga de relieve la forma en la que las lenguas y culturas en contacto (namtrik/español) abordan lo relacionado con lo sobrenatural, señalando las similitudes y la oportunidad de enriquecerse con las diferencias. A partir de este texto, se trabaja desde el punto de vista ortográfico, la hipersegmentación y la hiposegmentación de las palabras; desde lo fonético, las diferencias entre el sistema vocálico de ambas lenguas. También se busca la adquisición de nuevas unidades léxicas y la mejora de las destrezas relacionadas con la comprensión lectora y la expresión escrita. La segunda secuencia didáctica, titulada La luz es como el agua, a partir de la adaptación de un cuento de Gabriel García Márquez, busca crear un relato intercultural que les permita a los niños misak mediar entre la propia cultura y la de la L2 y establecer estrategias de mediación de significado. El objetivo se centra en orientar la reflexión hacia la semejanza de las relaciones familiares en las identidades en contacto, pese a las diferencias de contexto físico. En cuanto al aspecto fonológico se trabaja la oposición entre /d/ /t/; desde lo morfológico, la marca de género en adjetivos y sustantivos; con relación a lo sintáctico, el uso del artículo. Asimismo, se enfatiza en la adquisición de nuevas unidades léxicas y se ejercitan las competencias de lectura y producción escrita.

En la tercera y la cuarta secuencia, No todo es como parece Iy II se busca avanzar en una visión crítica de culturas diferentes a la propia —en el caso particular, la cultura misaksuperando los estereotipos hacia la vida urbana colombiana. La idea es profundizar en un análisis de la propia cultura, para de este modo potenciar una mirada exterior a la propia identidad. Desde el punto de vista morfológico, No todo es como parece I trabaja el uso de la marca de número en sustantivos y adjetivos; y en cuanto a lo ortográfico busca mejorar el uso correcto de las mayúsculas en el contexto de la adquisición de nuevas unidades léxicas y del desarrollo de las competencias de escritura y oralidad. Por su parte, No todo es como parece II, en lo ortográfico, busca mejorar el uso de la tilde, mientras que en lo sintáctico enfatiza en el uso del artículo y en la posición del adjetivo respecto al sustantivo. Esta última secuencia trabaja también, como las demás, la extensión del léxico y el desarrollo de las competencias globales de lectoescritura.

Las cuatro secuencias tienen en líneas generales la misma estructura: parten de una página introductoria en la que se describen los objetivos, los niveles de la lengua y las competencias propias del MAREP que se trabajarán, entre otros. A continuación, se presenta una actividad de anticipación o calentamiento (en las secuencias uno y dos con textos escritos 
y en las secuencias tres y cuatro con estímulos visuales) seguidos de ejercicios de comprensión de lectura y de expresión escrita. La segunda sección de cada secuencia corresponde a textos descriptivos y expositivos, recuadros con información gramatical y definiciones, orientados a saber más. En tercer término, las secuencias incluyen una sección de ejercicios en las diferentes competencias que se dirigen a la adquisición de nuevas unidades lexicales, al repaso de los aspectos formales y a la reflexión intercultural. Finalmente, cada secuencia incluye deberes para llevar a cabo en casa que buscan afianzar la adquisición de las destrezas y saberes aprendidos durante las sesiones presenciales de trabajo.

\section{Referencias bibliográficas}

Bodnar, Y. (1990): “Aproximación a la etnoeducación como elaboración teórica”. En Programa de Etnoeducación, Etnoeducación: conceptualización y ensayos, Bogotá, Colombia: La Programa, pp. 41-96.

Cabildo Indígena de Guambía (1994): Plan de vida del pueblo guambiano, Colombia: Cencoa.

Cabildo Indígena de Guambía (2005): Namui Kollimisak Mera Wam. La voz de nuestros mayores, Colombia: Editorial López.

Candelier, M.; A. Camilleri-Grima; V. Castellotti; J. F. De Pietro; I. Lörincz; F. J. Meissnery A. Schroder-Sura (2008): Marco de referencia para los enfoques plurales de las lenguas y las culturas (MAREP), Graz: European Centre for Modern Languages. https://carap.ecml.at/Portals/11/documents/CARAP_version3_ES_\%2015072010.pdf

Curnow, T. J. y A. J. Liddicoat (1998): "The Barbacoan languages of Colombia and Ecuador", Anthropological Linguistics, 40 (3), pp. 384-408.

DANE (2019): Población indígena de Colombia: resultados del censo nacional de población y vivienda 2018. https://www.dane.gov.co/files/investigaciones/boletines/gruposetnicos/presentacion-grupos-etnicos-2019.pdf

García, W. (1999): "Historia de las políticas educativas para grupos étnicos en las tres últimas décadas en Colombia". En Colombia Unicauca Ciencia, Memorias Tercer Coloquio de Historia de la Educación Colombiana, Popayán, Colombia: Universidad del Cauca, pp. 7985 .

Gardner, R. C. (2001): "Integrative motivation and second language acquisition”. En Dörney, Z. y R. Schmidt (Eds.), Motivation and second language acquisition, Honolulu, Hawái: University of Hawai'i, Second Language Teaching and Curriculum Center, pp. 1-19. 
Gardner, R. y W. Lambert (1972): Attitudes and Motivation in Second Language Learning, Rowley, MA: Newbury House.

Fantini, A. y A. Tirmizi (2006): "Exploring and Assessing Intercultural Competence”, World Learning Publications, 1. https://digitalcollections.sit.edu/worldlearning_publications/ $\underline{1 /}$

Landaburu, J. (2005): "Las lenguas indígenas en Colombia: presentación y estado del arte", Amerindia (29/30), pp.3-22. http://sedyl.cnrs.fr/amerindia/articles/pdf/A_2930_00.pdf

Liévano Aguirre, I. (1966): Los grandes conflictos sociales y económicos de nuestra historia, Bogotá, Colombia: Imprenta Nacional de Colombia.

López Aguilar, F. (2001): “Dos opuestos: civilización y barbarie, vistos desde la antropología de la complejidad", Anales de Antropología, 35 (1), pp. 79- 89. http://revistas.unam.mx/inde x.php/antropologia/article/view/14888/14187

Muelas, B., y L. Triviño (2011): Kusrennøpelai wamtsi. Gramática pedagógica de la lengua namtrik para maestros misak, Popayán: Universidad del Cauca.

Oliveras Vilaseca, Á. (2000): Hacia la competencia intercultural en el aprendizaje de una lengua extranjera: estudio del choque cultural y los malentendidos, Madrid: Edinumen.

República de Colombia (1991): Constitución Política de Colombia. http://www.banrep.gov.co/reg imen/.../cp91.pdf

Rojas, A. y E. Castillo (2004): Educar a los otros: políticas educativas y diversidad cultural en Colombia, Popayán, Colombia: Editorial Universidad del Cauca.

Trillos, M. (1999): “El entramado de la multiculturalidad: respuestas desde la etnoeducación”. En Aguirre, D. (Comp.), Culturas, Lenguas, Educación: memorias. Simposio de etnoeducación (VIII Congreso de Antropología), Barranquilla, Colombia: Universidad de Atlántico e ICANH, pp. 13-30.

Vásquez de Ruiz, B. (2000): "Guambiano: algunos aspectos sobre morfología nominal". En González de Pérez, M. S. y M. L. Rodríguez de Montes (eds.), Lenguas indígenas de Colombia: Una visión descriptiva, Bogotá: Instituto Caro y Cuervo, pp. 155-156. 


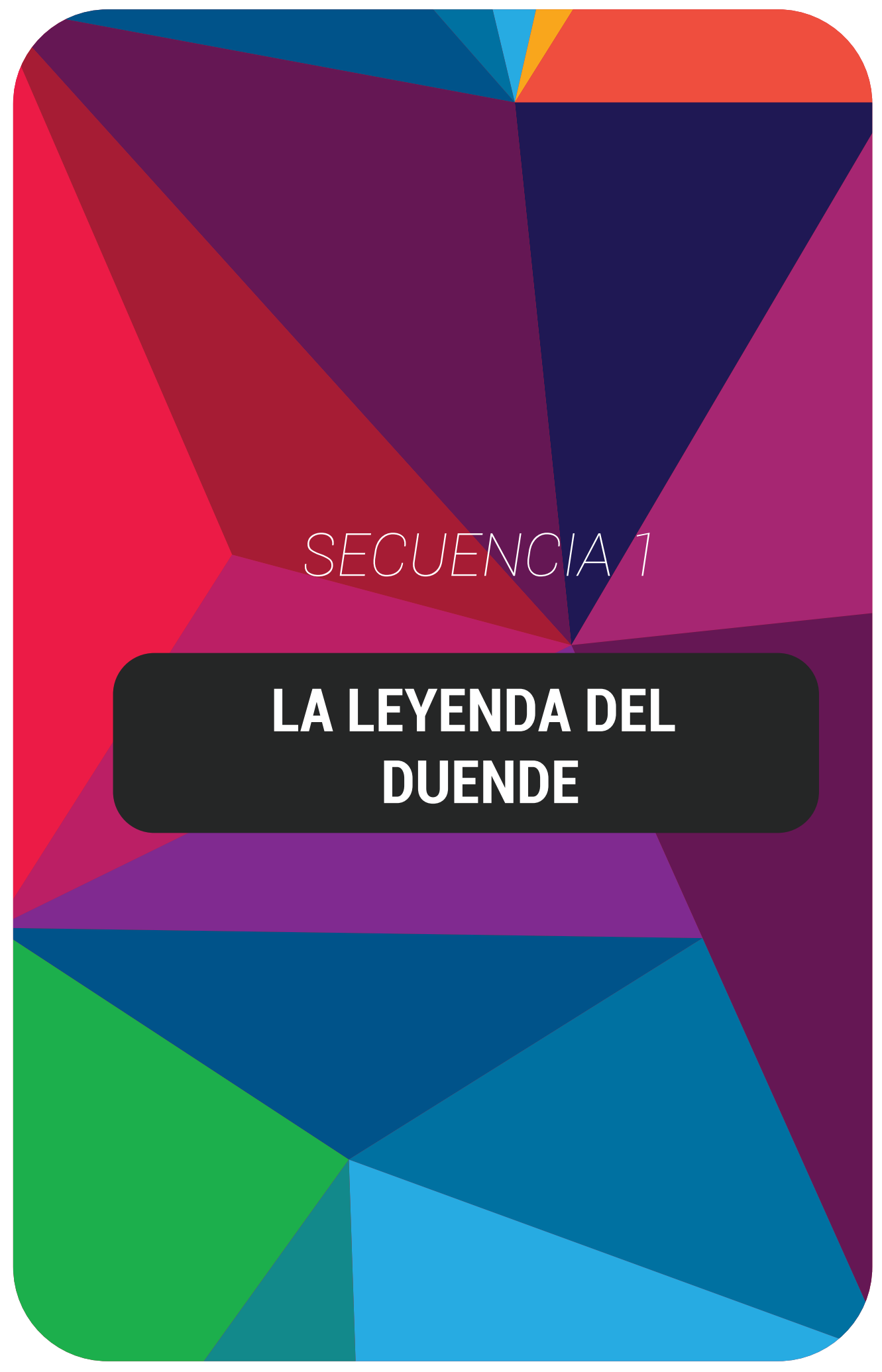




\section{SECUENCIA 1}

\section{ESPAÑOL COMO L2}

\begin{tabular}{|c|c|}
\hline Título & La leyenda del duende \\
\hline Material impreso & Sí \\
\hline Autor & Mónica Emma Lucía Chamorro Mejía \\
\hline Objetivos & $\begin{array}{l}\text { Establecer un diálogo intercultural, a partir } \\
\text { de leyendas mitológicas de la LM y de la L2, } \\
\text { en el que se ponga de relieve la forma en la } \\
\text { que ambas lenguas/culturas abordan lo } \\
\text { sobrenatural, señalando las similitudes y la } \\
\text { oportunidad de enriquecerse con las } \\
\text { diferencias. } \\
\text { Analizar la correcta segmentación de las } \\
\text { palabras en español, con relación al adjetivo } \\
\text { y el sustantivo. } \\
\text { Comprender las diferencias y semejanzas } \\
\text { entre el sistema vocálico namtrik/español. } \\
\text { Mejorar las destrezas relacionadas con la } \\
\text { comprensión lectora. } \\
\text { Mejorar las destrezas relacionadas con la } \\
\text { producción escrita. } \\
\text { Adquirir nuevas unidades léxicas. }\end{array}$ \\
\hline Destrezas & Comprensión lectora y expresión escrita \\
\hline Nivel & B2 \\
\hline Destinatario & $\begin{array}{l}\text { Niños de quinto grado de educación primaria } \\
\text { hablantes de namtrik }\end{array}$ \\
\hline Contenidos lingüísticos & $\begin{array}{l}\text { Ortografía: hipo e hiper segmentación } \\
\text { Fonética/Fonología: el sistema vocálico del } \\
\text { español. }\end{array}$ \\
\hline Contenidos interculturales & $\begin{array}{l}\text { Competencia de mediación: “...que dé } \\
\text { sentido a todas las 'puestas en relación', entre } \\
\text { lenguas, entre culturas y entre personas.” } \\
\text { (MAREP, 2008) }\end{array}$ \\
\hline
\end{tabular}


Describe brevemente la imagen que está al lado del texto El duende.

2 Tomando en cuenta esta ilustración, trata de imaginar el tema del texto.

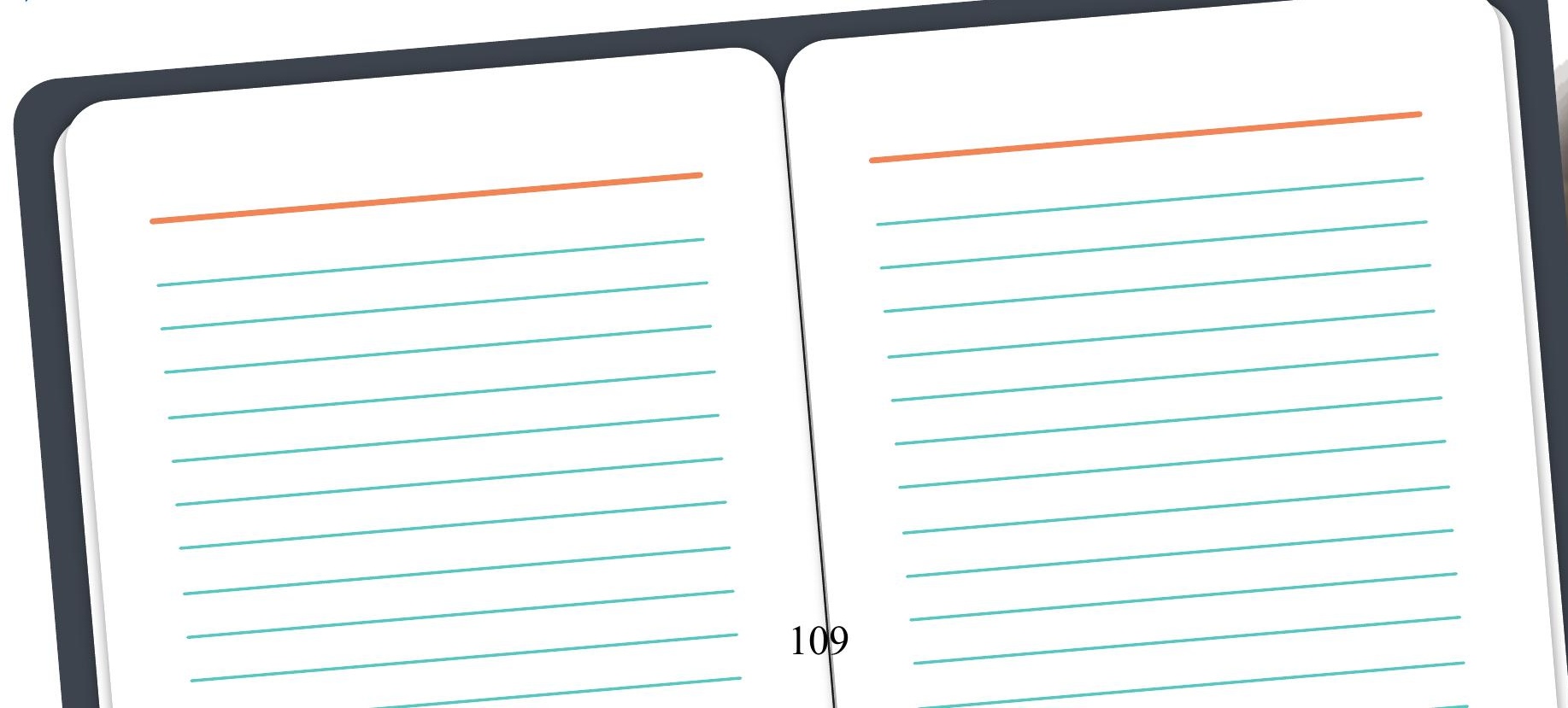



4 A continuación relaciona las dos columnas, uniendo con una flecha las palabras que tienen significados parecidos.

\section{Recuerda que}

Las palabras que tienen un significado igual o muy parecido se denominan sinónimos.

$\begin{array}{ll}\text { Poderoso } & \text { Diablo } \\ \text { Furioso } & \text { Distancia } \\ \text { Atraer } & \text { Potente } \\ \text { Lejanía } & \text { Altivo } \\ \text { Expulsar } & \text { Rabioso } \\ \text { Demonio } & \text { Echar } \\ \text { Orgulloso } & \text { Seducir }\end{array}$

5 Junto a tu compañero de pupitre responde a las siguientes preguntas ¿Qué emoción te produce el relato de El duende? ¿Por qué? 


\section{A CONTINUACIÓN}

¿Qué emoción te produce el relato de El duende? ¿Por qué?

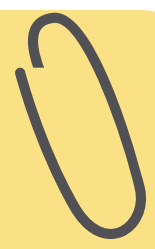

Las historias, narraciones o relatos pueden provocar emociones diferentes. La comedia, por ejemplo, provoca alegría o risa y la tragedia, tristeza. Las historias que provocan miedo pertenecen al género de terror y en muchos casos están relacionadas con hechos no explicables, por lo cual es necesario recurrir a lo sobrenatural o a lo fantástico. 
Describe los siguientes personajes que aparecen en el texto y haz un dibujo de cada uno de ellos. Vístelos con el traje de la comunidad misak.

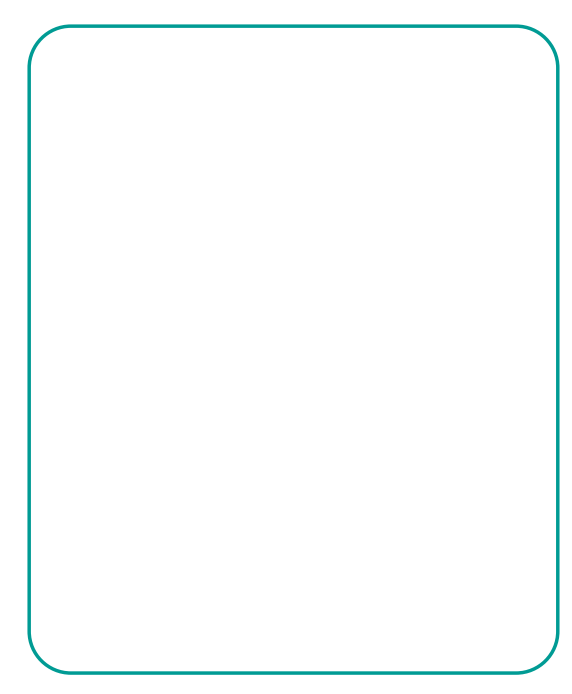

Dios Padre

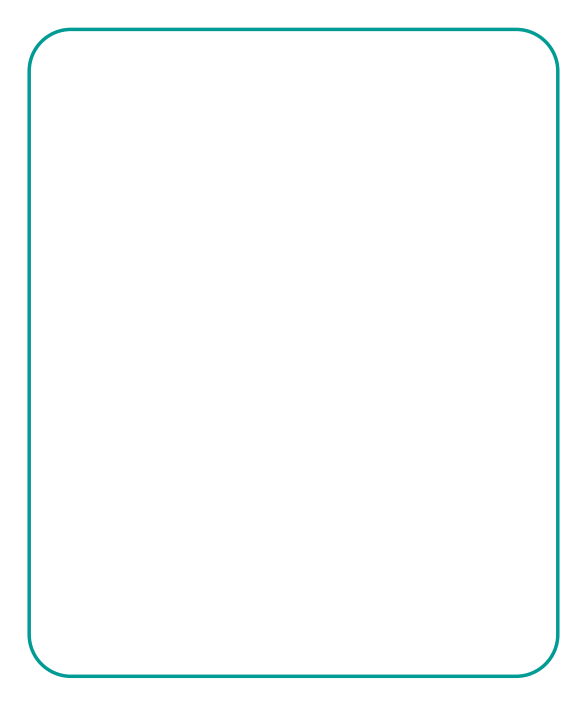

Ángeles

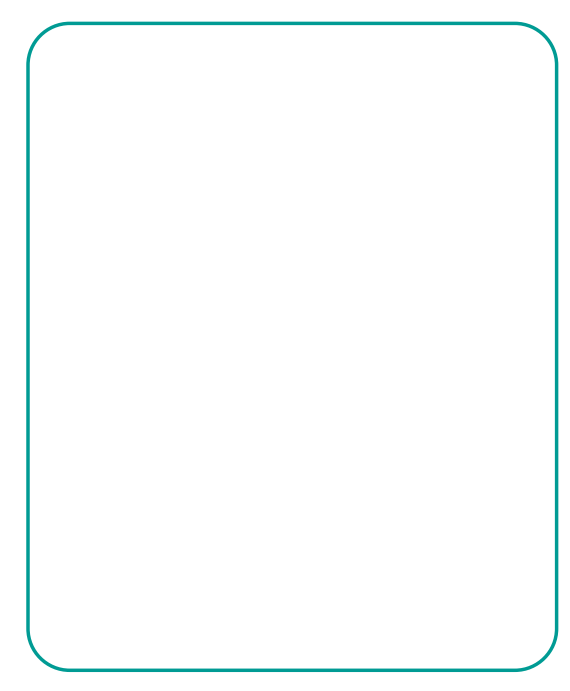

Luzbel

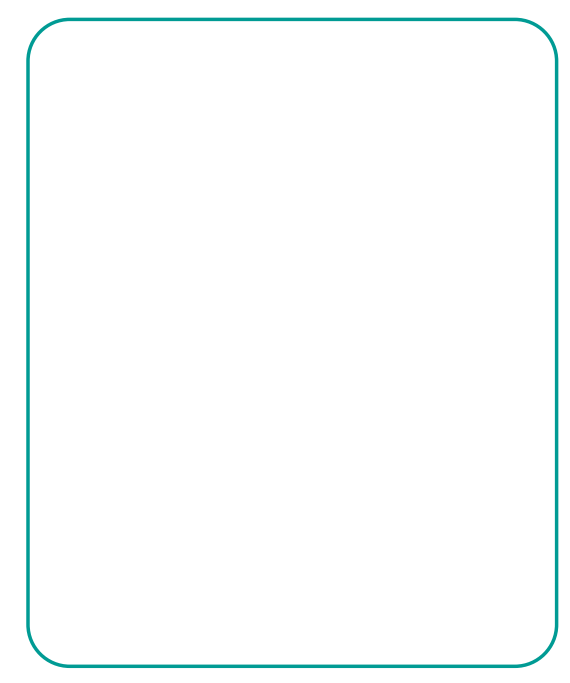

Duende 
¿Qué es lo que más te gusta del relato El duende? ¿Qué es lo que menos te gusta?

Describe los dos instrumentos musicales representados en las siguientes imagenes:
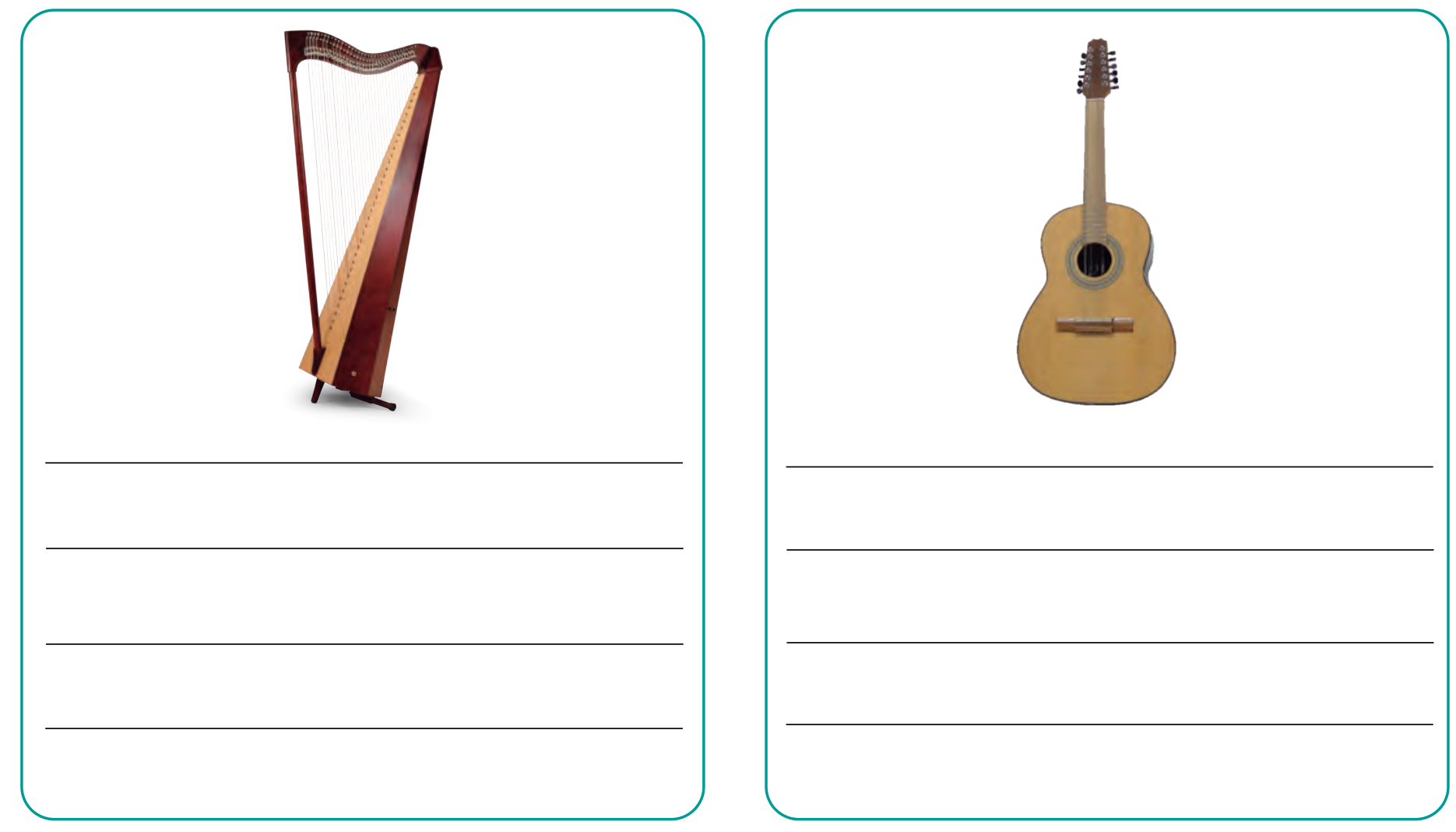

\section{Expresión oral}

¿Conoces algún instrumento musical parecido en el resguardo de Guambía? ¿Quién lo toca y en qué ocasiones? ¿T15 gusta su sonido? 
Al escribir es importante poner atención a la correcta separación de las palabras. Intenta separar cada una de las palabras con guiones para que reflexiones respecto a su extensión.

Ejemplo: Lamuchacha de la tienda

La-muchacha-de-la-tienda

Abrola puerta
Abro-la-puerta

Nota: En español los artículos definidos (el, la, los, las) no se unen nunca con el nombre o sustantivo (Ejemplo: el gato, los niños, las casas, la escuela).

PARA LA CASA

¿Conoces alguna narración 0 leyenda de la cultura misak que produzca

temor o miedo? Escríbela en 15 renglones para la próxima clase. Si no conoces ninguna imagínala y escríbela.

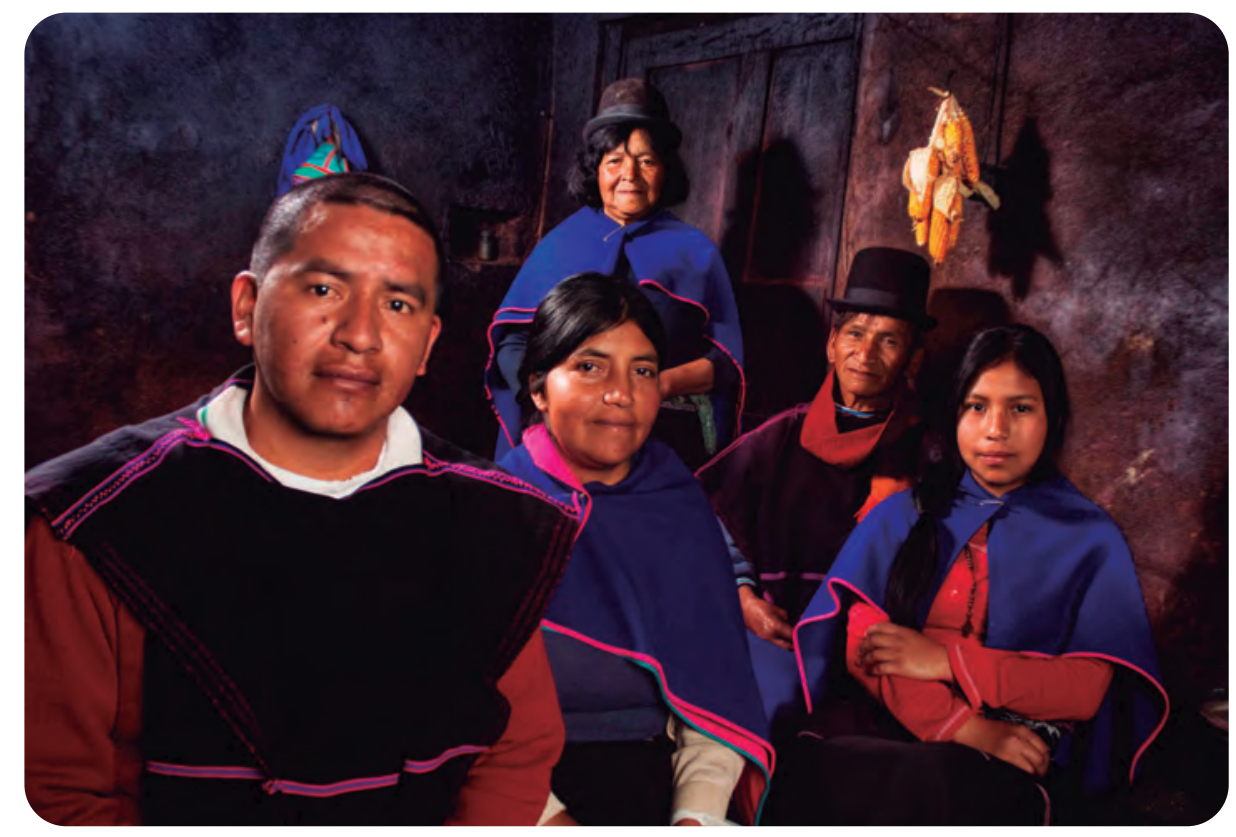




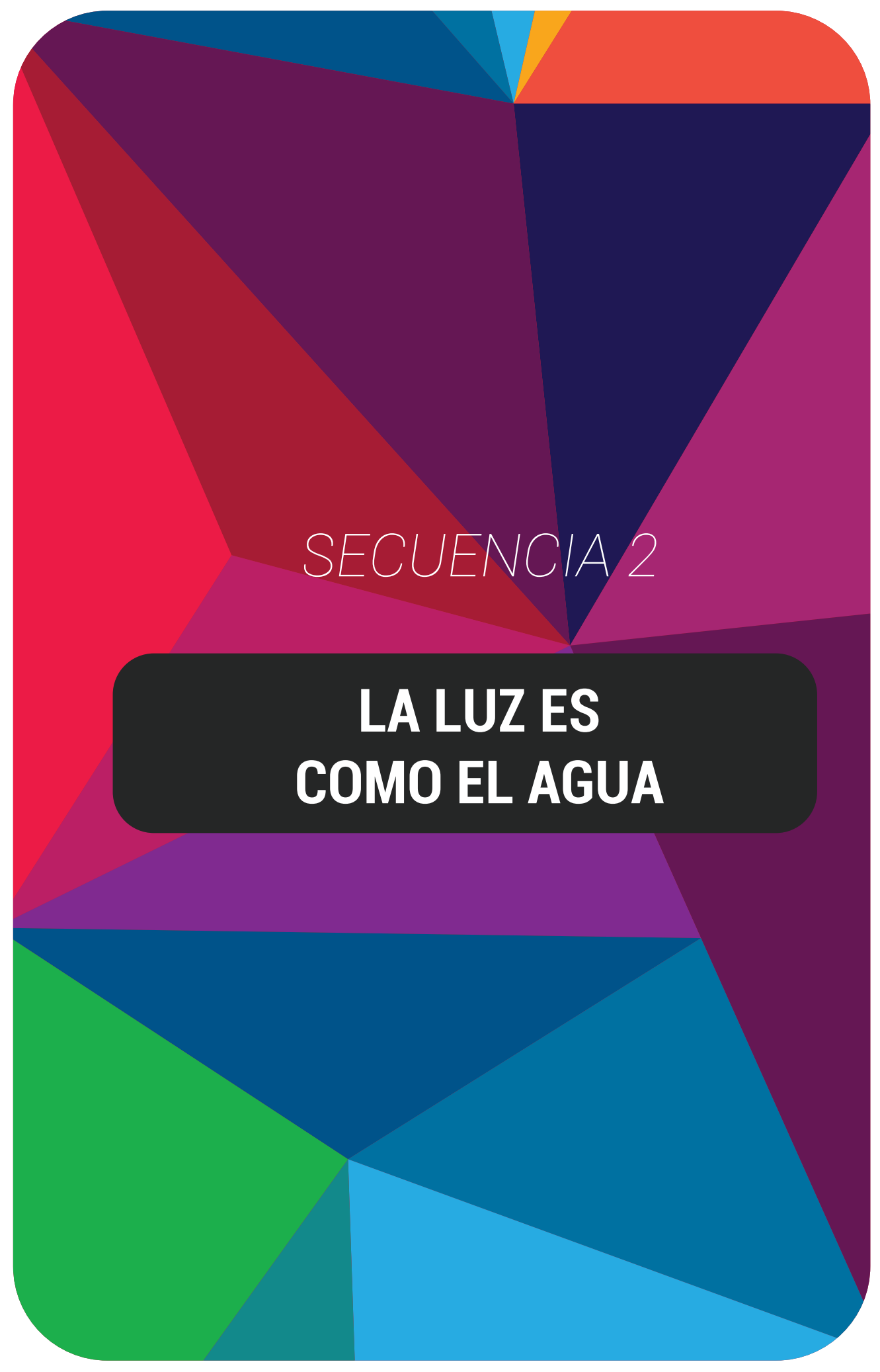




\section{SECUENCIA 2}

\section{ESPAÑOL COMO L2}

\begin{tabular}{|c|c|}
\hline Título & La luz es como el agua \\
\hline Material impreso & sí \\
\hline Autor & Mónica Emma Lucía Chamorro Mejía \\
\hline Objetivos & $\begin{array}{l}\text { Trasladar la acción del relato al contexto próximo del } \\
\text { resguardo, con el fin de crear un relato intercultural que } \\
\text { les permita mediar entre la propia cultura y la de la L2. } \\
\text { Permitir que los alumnos reflexionen sobre las diferencias } \\
\text { del contexto físico en oposición a la semejanza de las } \\
\text { relaciones familiares en ambas culturas. } \\
\text { Analizar la oposición fonológica /d/ } / \mathrm{t} / \text {. } \\
\text { Ejercitarse en el uso de la marca de género en el adjetivo } \\
\text { y en el sustantivo. } \\
\text { Recordar la importancia del uso del artículo. } \\
\text { Mejorar las destrezas relacionadas con la comprensión } \\
\text { lectora. } \\
\text { Mejorar las destrezas relacionadas con la producción } \\
\text { escrita. } \\
\text { Adquirir nuevas unidades léxicas. }\end{array}$ \\
\hline Destrezas & Comprensión lectora y expresión escrita \\
\hline Nivel & B2 \\
\hline Destinatario & $\begin{array}{l}\text { Niños de quinto grado de educación primaria hablantes } \\
\text { de namtrik }\end{array}$ \\
\hline Contenidos lingüísticos & $\begin{array}{l}\text { Fonético/fonológico: oposición fonológica entre /d/ / } \\
\text { t/; morfología: uso de la marca de género y } \\
\text { concordancia entre artículo y sustantivo. }\end{array}$ \\
\hline Contenidos interculturales & $\begin{array}{l}\text { Competencia de mediación: “...que dé sentido a todas } \\
\text { las 'puestas en relación', entre lenguas, entre culturas y } \\
\text { entre personas". MAREP (2008) } \\
\text { Competencia de negociación: “una competencia de } \\
\text { negociación, que fundamente la dinámica de los } \\
\text { contactos y relaciones en contexto de alteridad". MAREP } \\
\text { (2008) }\end{array}$ \\
\hline
\end{tabular}




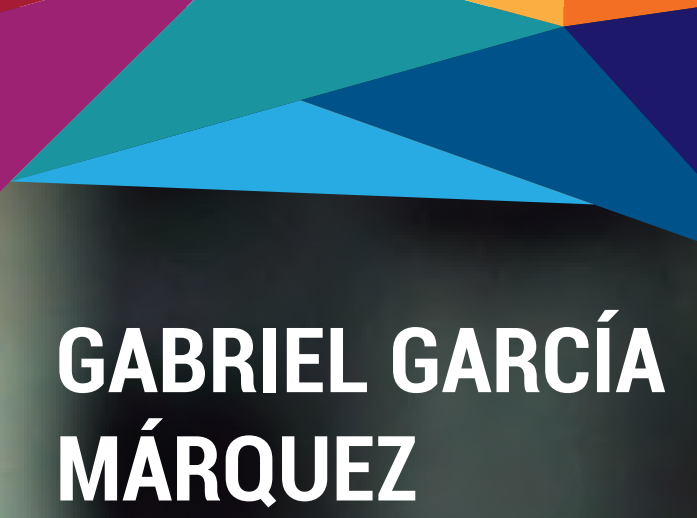

Autor colombiano.Destacó, sin duda, como uno de los más grandes narradores de la literatura del siglo XX. Figura fundamental del conocido boom latinoamericano, sobre todo por su trabajo dentro del realismo mágico. En 1982, García Márquez recibió el galardón más importante de su carrera, el Premio Nobel de Literatura, otorgado como reconocimiento a toda su obra.

García Márquez nació y se crió en Aracataca, localidad que luego tendría una importancia clave en muchas de sus obras más conocidas, en una familia cuyo abuelo, coronel, fue una gran influencia en el joven escritor.

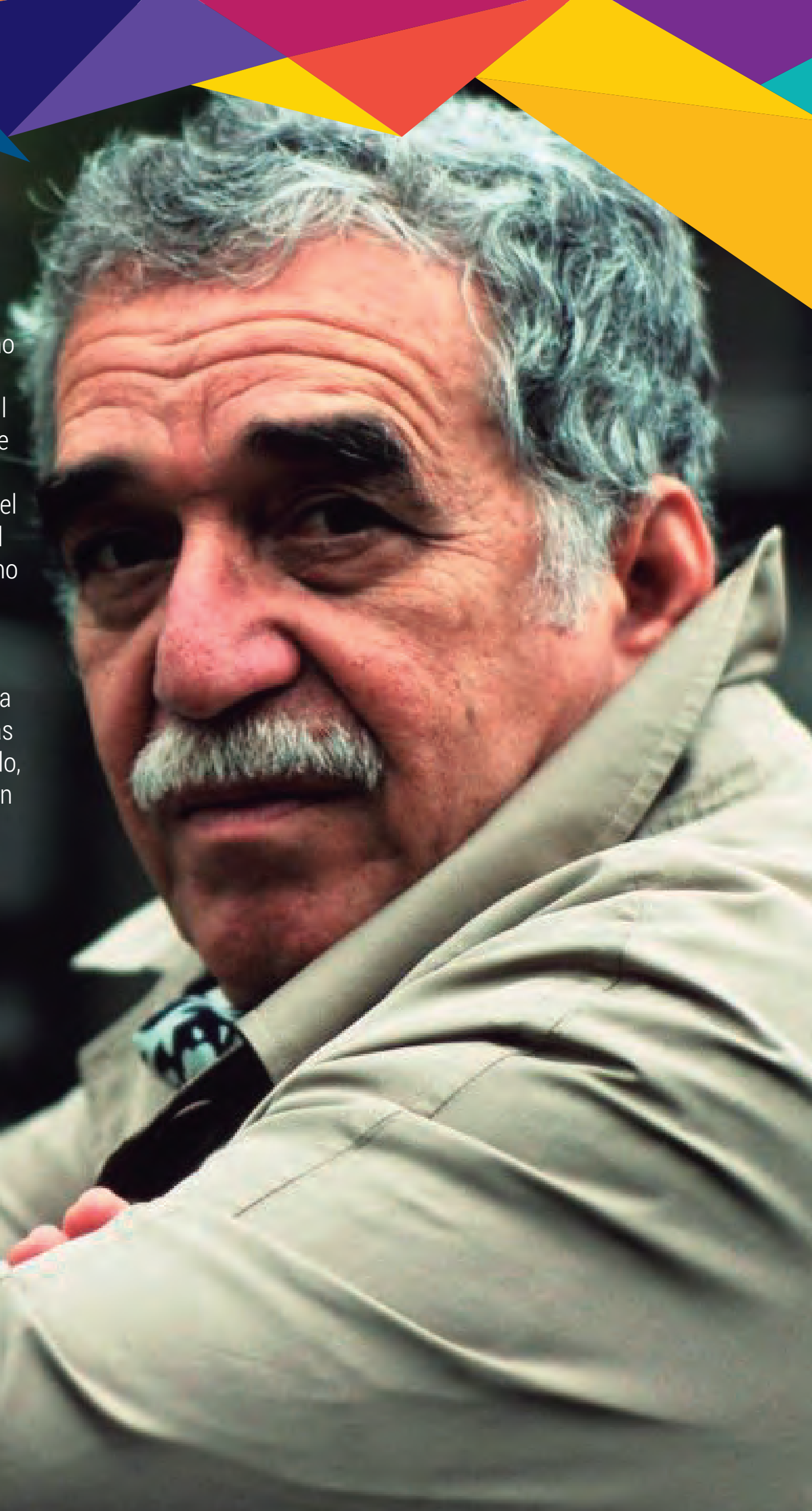




\section{6 lexpes \\ cosere ef argerer}

\section{Gabriel García Márquez}

En Navidad los niños volvieron a pedir un bote de remos.

-De acuerdo -dijo el papá, lo compraremos cuando volvamos a Cartagena.

Totó, de nueve años, y Joel, de siete, estaban más decididos de lo que sus padres creían.

No -dijeron a coro-. Nos hace falta ahora y aquí.

Para empezar -dijo la madre-, aquí no hay más aguas navegables que la que sale de la ducha.

Tanto ella como el esposo tenían razón. En la casa de Cartagena de Indias había un patio con un muelle sobre la bahía, en cambio aquí en Madrid vivían apretados en un apartamento. Pero al final ni él ni ella pudieron negarse, porque les habían prometido un bote de remos si se ganaban el primer puesto del tercer año de primaria y se lo habían ganado. Así que el papá lo compró sin decirle nada a su esposa.

La noche del miércoles los padres se fueron al cine. Los niños cerraron las puertas y

las ventanas y rompieron la bombilla encendida de una lámpara de la sala.

Un chorro de luz dorada y fresca como el agua empezó a salir de la bombilla rota y lo dejaron correr hasta que el nivel llegó a cuatro palmos. Entonces sacaron el bote y navegaron a placer por la casa. 
Haz una lectura silenciosa de la adaptación del texto La luz es como el agua de Gabriel García Márquez.

¿Cuál es la idea central del texto? Con tu compañero de pupitre haz un breve resumen.

Recuerda que en español existen dos consonantes que tienen una pronunciación parecida pero que representan sonidos diferente, la letra t y la letra d. Por esta razón, no debes decir:

Tengo tiez años.

Tengo diez años.

Aprenter mejor a hablar el español.

Aprender mejor a hablar el español. 


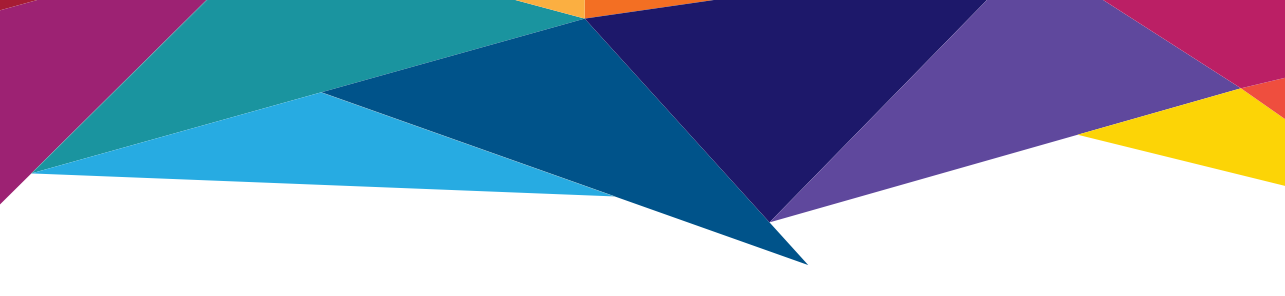

Con tu compañero de pupitre responde a las siguientes preguntas:

¿Dónde ocurre la historia? ¿En el campo o en una ciudad? ¿En una casa o en un apartamento?
¿Cuál es el regalo que quieren los niños? ¿Por qué a los padres les parece un regalo poco útil?
Describe a los protagonistas de la historia.
¿Cómo emplean el regalo los niños?
¿Los niños consiguen el regalo que desean? ¿Cómo lo consiguen?

7 Encuentra las siguientes palabras en el texto y haz una frase con cada una de ellas:

Bote

Remos

Navegables

Bombilla

Palmos 
Para redactar las frases anteriores no olvides tener en cuenta:

En español, las terminaciones de ciertas palabras (sustantivos, adjetivos, artículos y algunos pronombres) nos indican su género, es decir si son femeninas o masculinas. Aunque hay muchas excepciones, en general se puede decir que las palabras terminadas en -o son masculinas y las terminadas en -a son femeninas (ej. perro - lindo - tuyo; perra - linda - tuya). Al escribir o al hablar, estamos obligados a usar el mismo género en una misma frase.

Ejemplo:

Trajo la perro y lo bañó.

Trajo el perro y lo bañó.

La escuela es limpio.

La escuela es limpia .

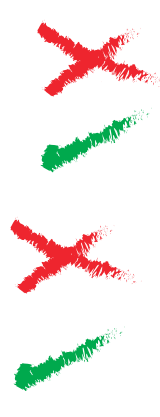
A continuación, imagina qué aspectos de La luz es como el agua, tendrías que 8 modificar para ubicar el cuento en tu resguardo y transformar a los protagonistas en miembros de la comunidad misak. Responde a las siguientes preguntas:

Si el relato sucediera en el resguardo de Guambía, ¿la familia viviría en una casa o en un apartamento?

¿Los niños pedirían el mismo regalo?

¿Un bote de remos tendría alguna utilidad en el resguardo? 
A continuación, escribe un relato de máximo 30 renglones en el que narres lo que pasaría si el cuento La luz es como el agua, sucediera dentro del resguardo y con personas de la comunidad misak 


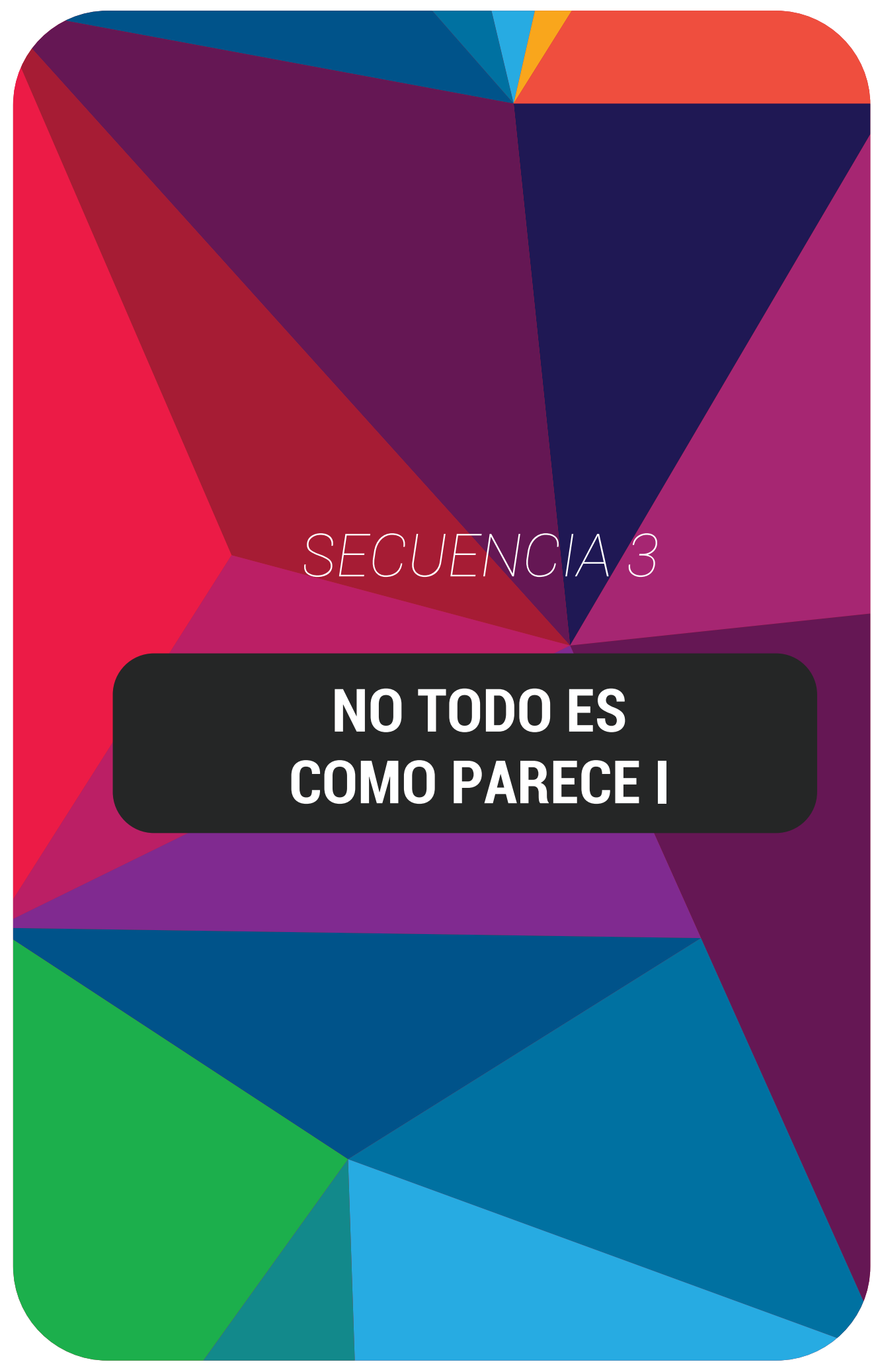




\section{SECUENCIA 3}

\section{ESPAÑOL COMO L2}

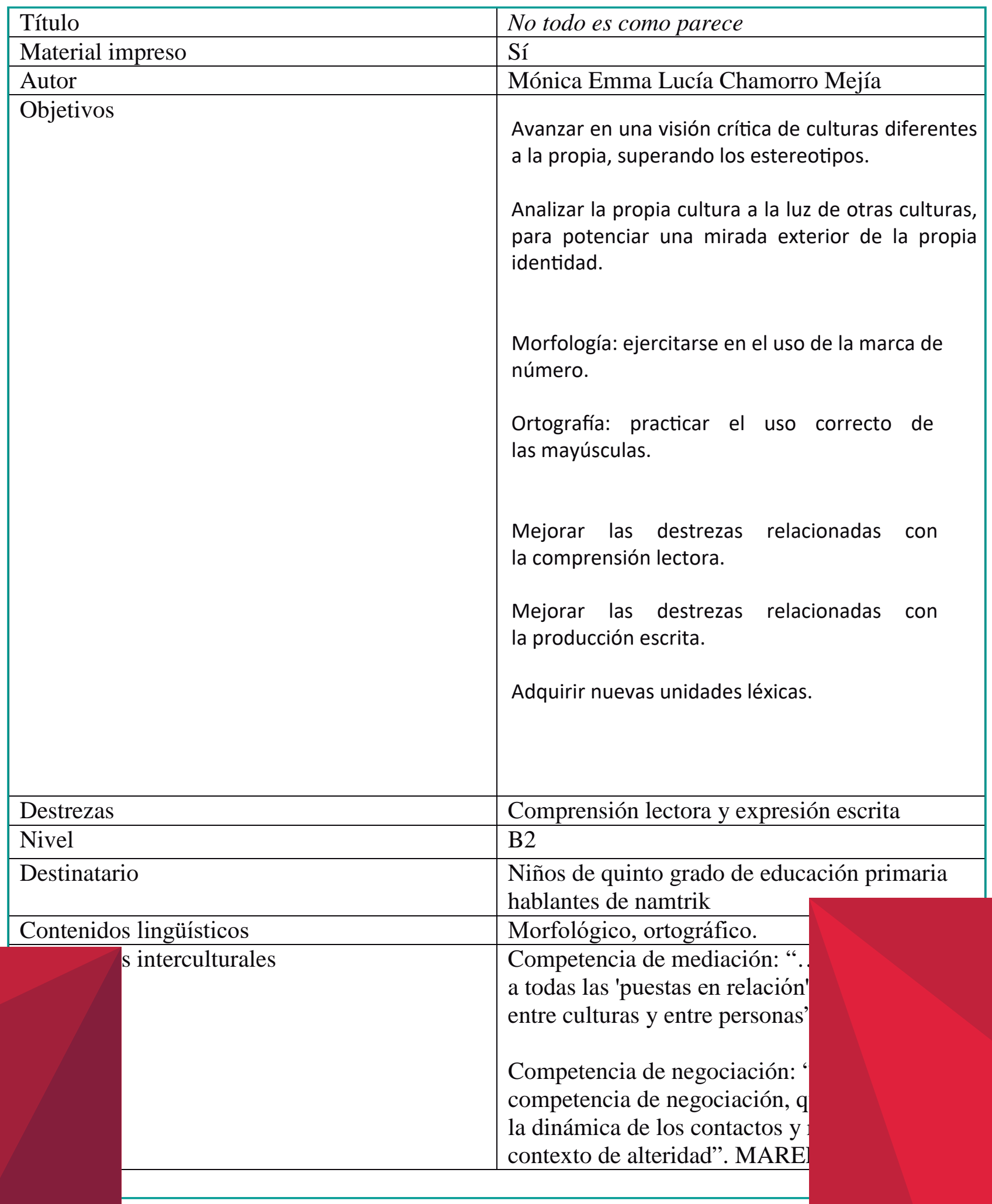




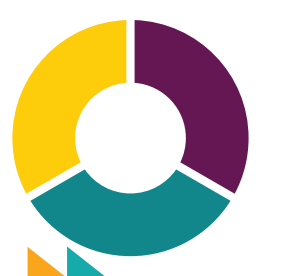

\section{ANTICIPACIÓN}

Con tu compañero de pupitre, observa las siguientes tres fotografías e imagina las respuestas de las siguientes preguntas:

¿De qué país crees que es cada persona?

¿Crees que nació en alguna ciudad que conoces o que has oído nombrar? ¿Cuál? ¿A qué se dedica?
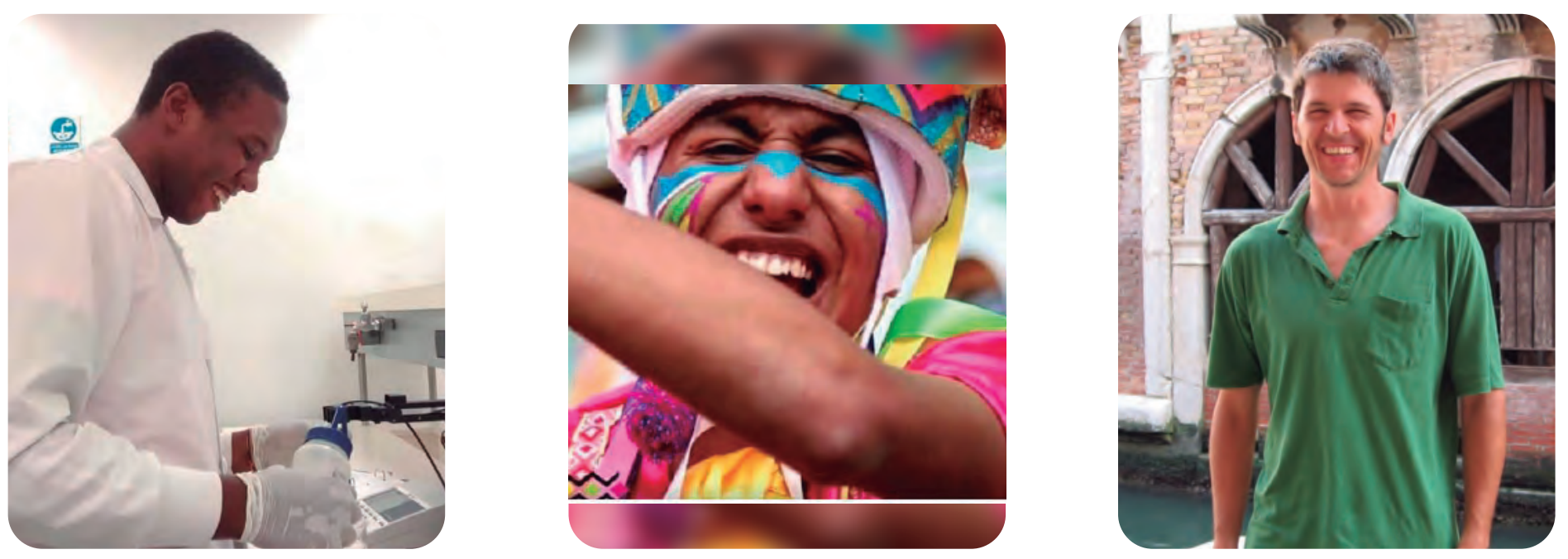

Lee tus respuestas al grupo y compáralas con las de tus compañeros. 


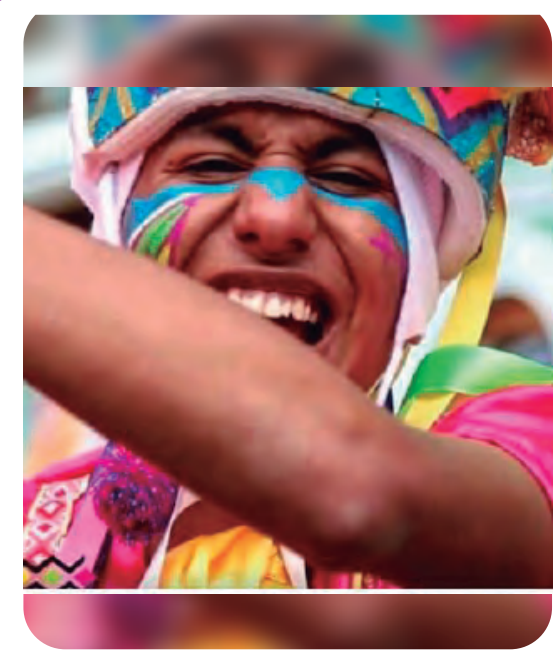

\section{Ricardo Narváez}

Nació en Sandoná, departamento de Nariño. Lo que más le gusta de su ciudad natal son los carnavales y los festivales, el clima templado y el calor humano de las personas.

Su comida favorita es el cuy y el arroz con pollo. Dedica su tiempo libre a bailar danzas folklóricas.

\section{Pedro Pablo Blanco}

Nació en Bogotá, la capital de Colombia. Lo que más le gusta de su ciudad son los cerros que la rodean y su gran vida cultural. En su tiempo libre le encanta ir a cine con su novia, escuchar música o tocar algún instrumento. Su comida favorita es el ajiaco y los pasteles de arracacha.
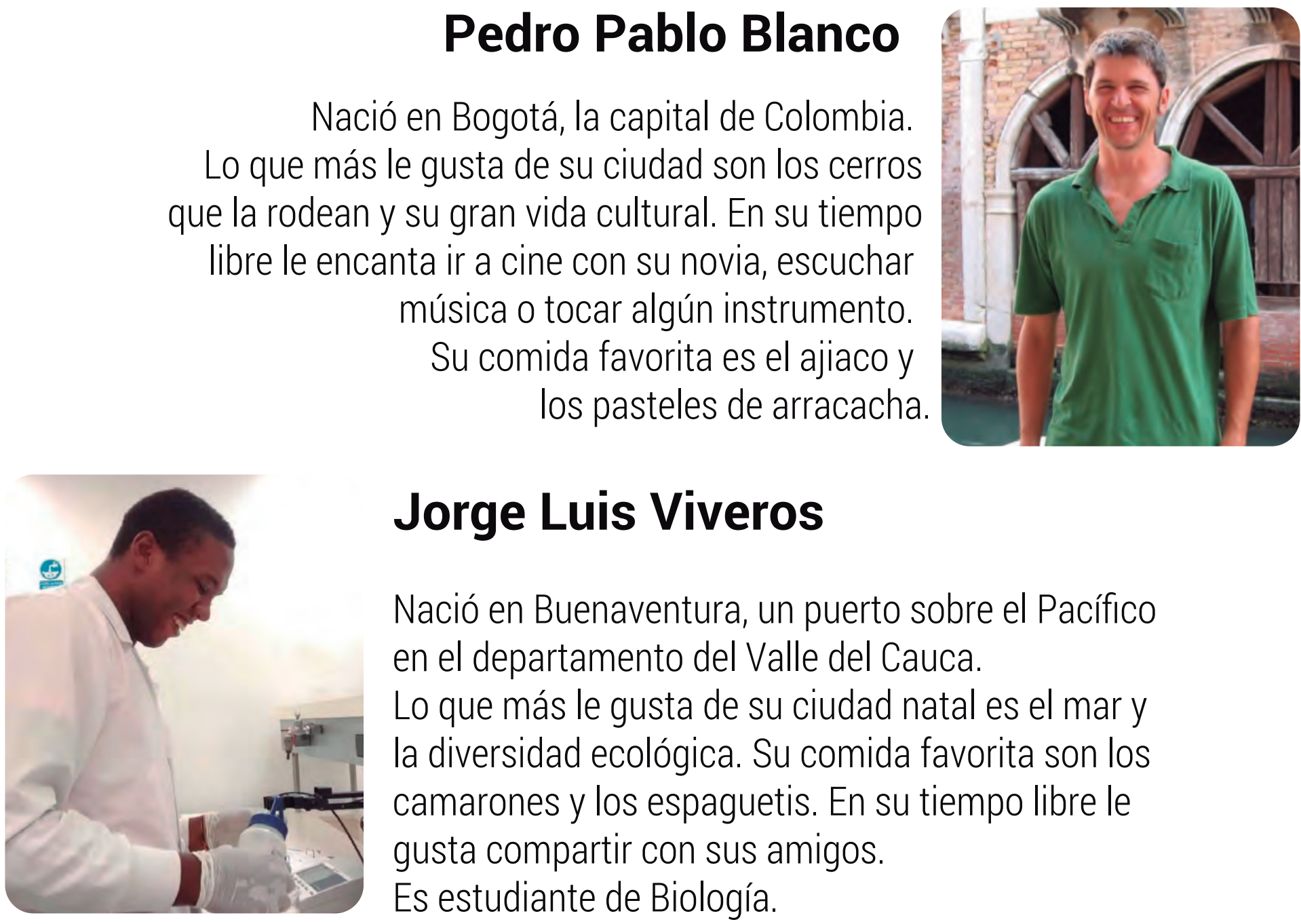

\section{Jorge Luis Viveros}

Nació en Buenaventura, un puerto sobre el Pacífico en el departamento del Valle del Cauca.

Lo que más le gusta de su ciudad natal es el mar y la diversidad ecológica. Su comida favorita son los camarones y los espaguetis. En su tiempo libre le gusta compartir con sus amigos.

Es estudiante de Biología. 


\section{Para realizar esta lectura ten en cuenta:}

En español siempre se debe señalar la cantidad de personas, animales o cosas a las que nos estamos refiriendo, es decir que debemos marcar su número. Cuando hablamos de una sola persona (o animal o cosa) decimos que es singular; si es más de una decimos que es plural.

La regla general indica que basta añadir una -s al singular, si termina en vocal, o -es si termina en consonante (ej. perro > perros; lindo > lindos; árbol > árboles; canción > canciones).

Al escribir o al hablar, estamos obligados a usar el mismo número en una misma frase.

Ejemplos: Los perro grandes corre rápido Los perros grandes corren rápido

Compara tus hipótesis con la nota biográfica de Pedro Pablo, Jorge Luis y Ricardo. ¿Coinciden tus respuestas? ¿Cuáles son diferentes?

\section{*Hipótesis: 1. f. \\ Suposición de algo posible o imposible para sacar de ello una consecuencia. (Diccionario de la R.A.E}



Ve a la biblioteca de tu escuela. Allí, junto a tu compañero de pupitre, escoge una de las siguientes culturas e investiga sobre ella:
CHINA
RUSA
ESPAÑOLA

A continuación responde a las siguientes preguntas:

CULTURA:

COSTUMBRES:

RELIGIÓN:

FESTIVIDADES:

LENGUA:

ASPECTO FÍSICO (REALIZA UN DIBUJO): 
En Colombia una de las festividades más importantes es la Navidad. Veamos cómo se celebra en Bogotá, la capital del país:
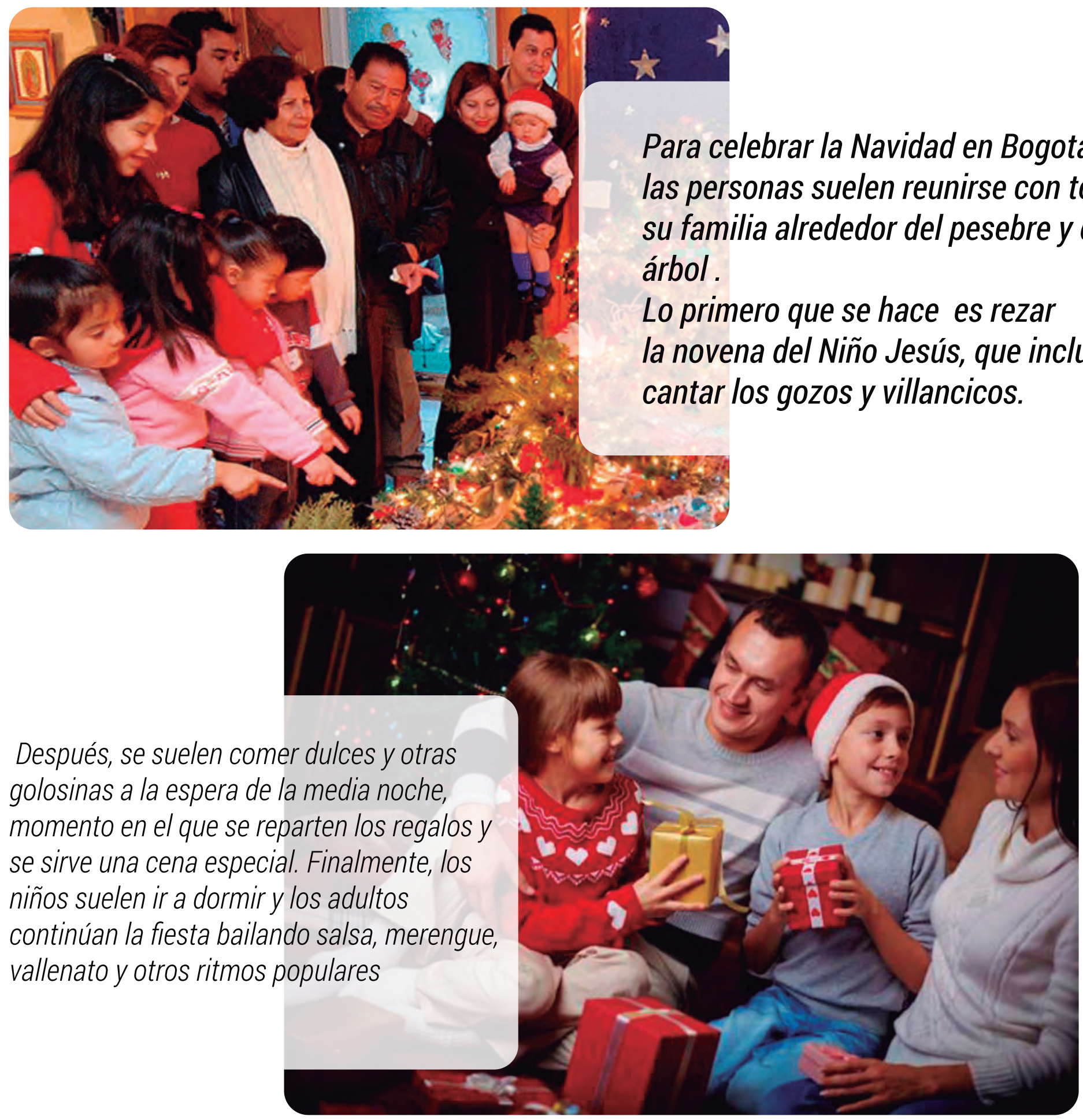

Después, se suelen comer dulces y otras golosinas a la espera de la media noche, momento en el que se reparten los regalos y se sirve una cena especial. Finalmente, los niños suelen ir a dormir y los adultos continúan la fiesta bailando salsa, merengue, vallenato y otros ritmos populares 


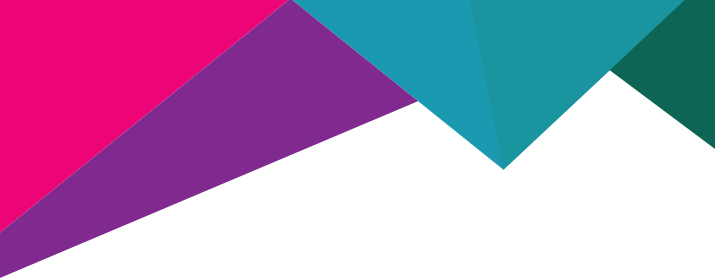

\section{0}

Expón tus respuestas al grupo y responde a las siguientes preguntas:

¿A qué cultura de las estudiadas

(rusa, china, española) se parece más el pueblo misak? ¿A cuál menos? ¿Por qué?

¿Cuál te gusta más? ¿Por qué?

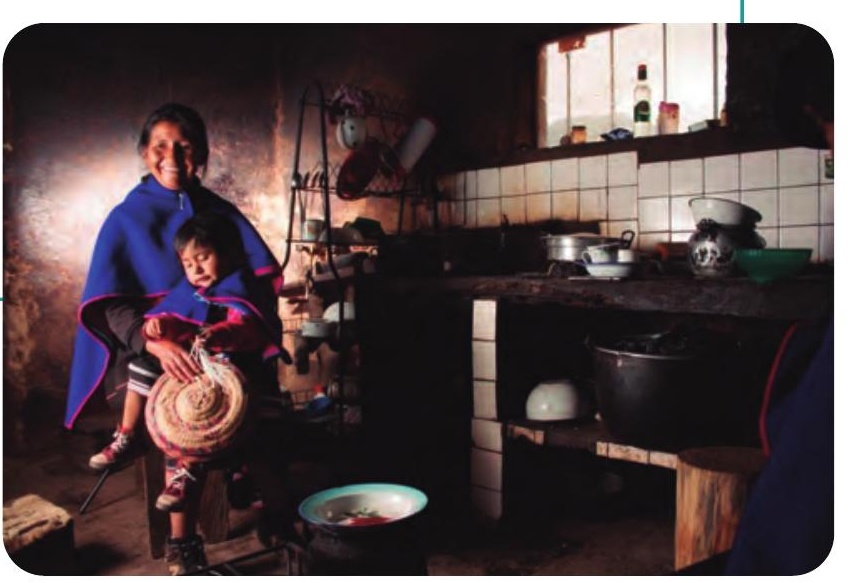

\section{EN CASA:}

Describe tu cultura, tomando en cuenta los aspectos estudiados en el ejercicio anterior 


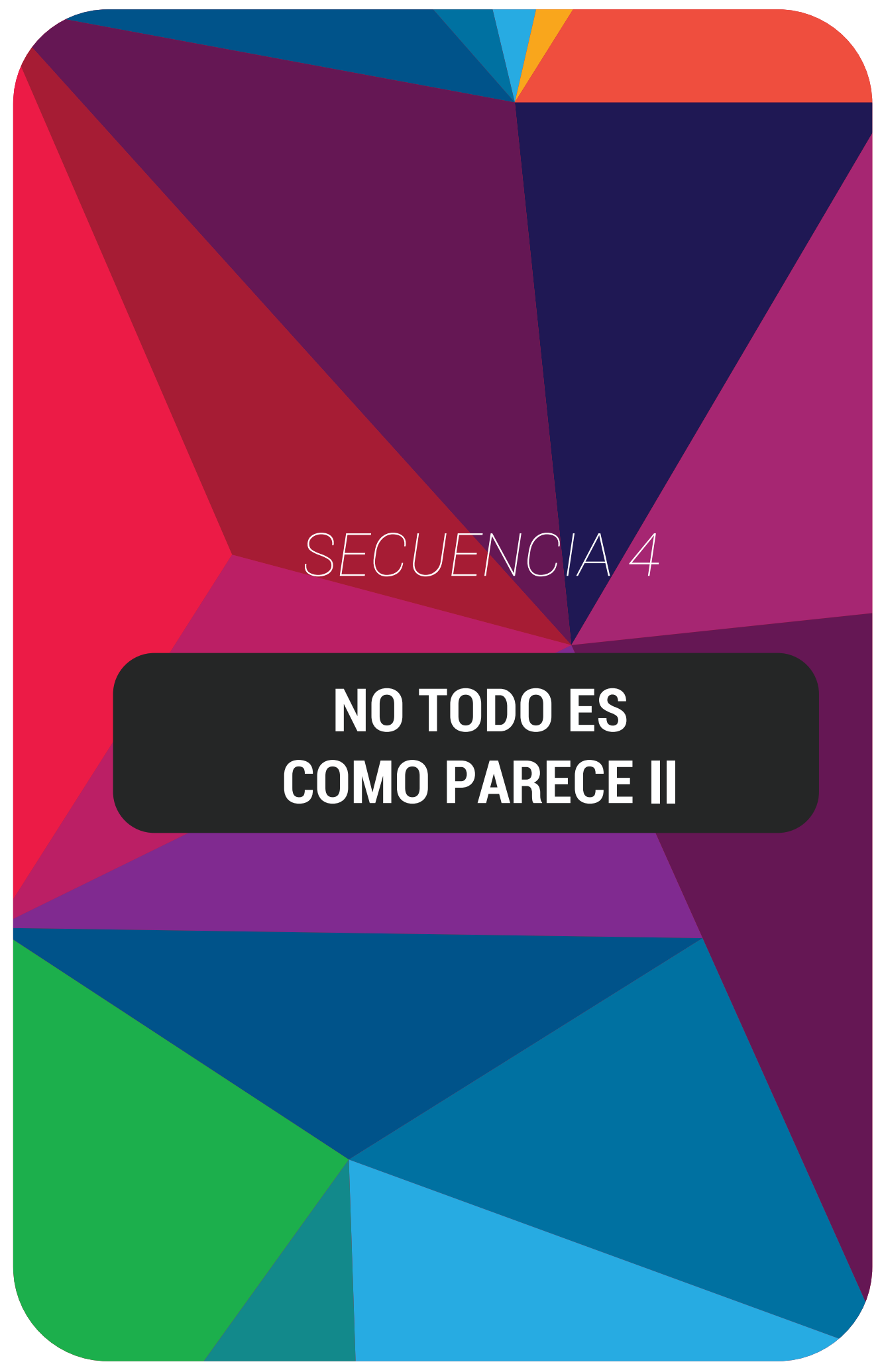




\section{SECUENCIA 4}

\section{ESPAÑOL COMO L2}

\begin{tabular}{|c|c|}
\hline Título & Nada es lo que parece 2 \\
\hline Material impreso & Sí \\
\hline Autor & Mónica Emma Lucía Chamorro Mejía \\
\hline Objetivos & 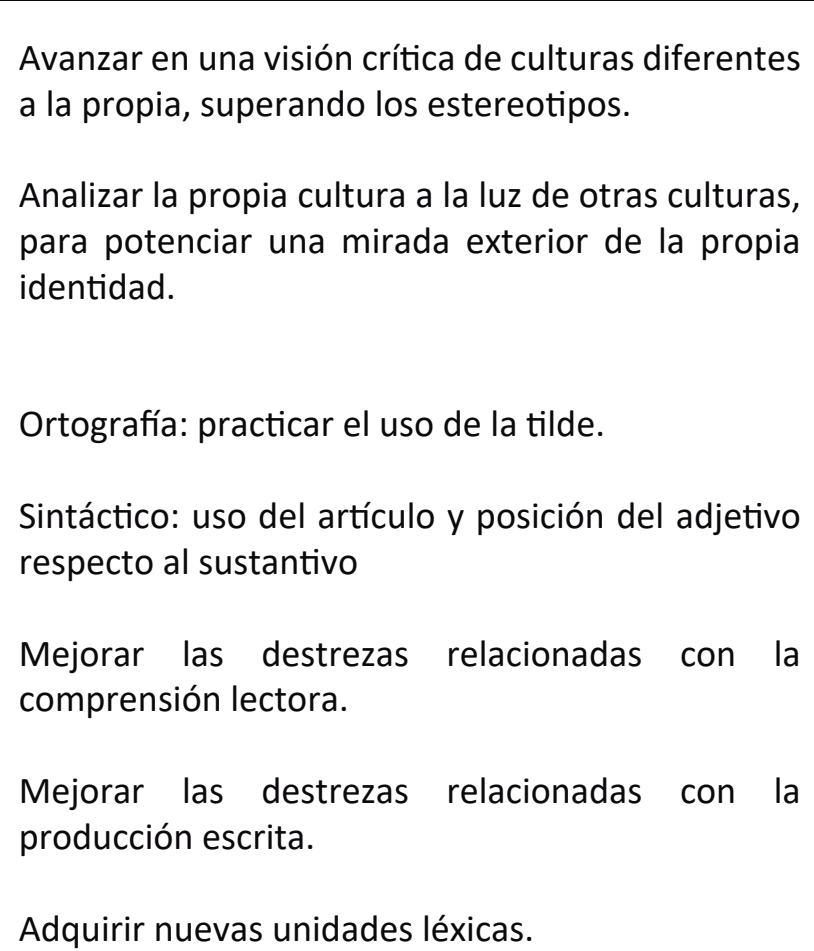 \\
\hline Destrezas & Comprensión lectora y expresión escrita \\
\hline Nivel & B2 \\
\hline Destinatario & $\begin{array}{l}\text { Niños de quinto grado de educación primaria } \\
\text { hablantes de namtrik }\end{array}$ \\
\hline Contenidos linguisticos & Ortografía, sintaxis \\
\hline Contenidos interculturales & $\begin{array}{l}\text { Competencia de mediación: “....que dé sentido } \\
\text { a todas las 'puestas en relación', entre lenguas, } \\
\text { entre culturas y entre personas”. } \\
\text { Competencia de negociación: “una } \\
\text { competencia de negociación, que fundamente } \\
\text { la dinámica de los contactos y relaciones en } \\
\text { contexto de alteridad”. MAREP (2008) }\end{array}$ \\
\hline
\end{tabular}


Ubica en el mapa de Colombia los siguientes departamentos:

Nariño (Pasto)

Cundinamarca (Bogotá)

Antioquia (Medellín)

Valle del Cauca (Cali)

Cauca (Popayán)

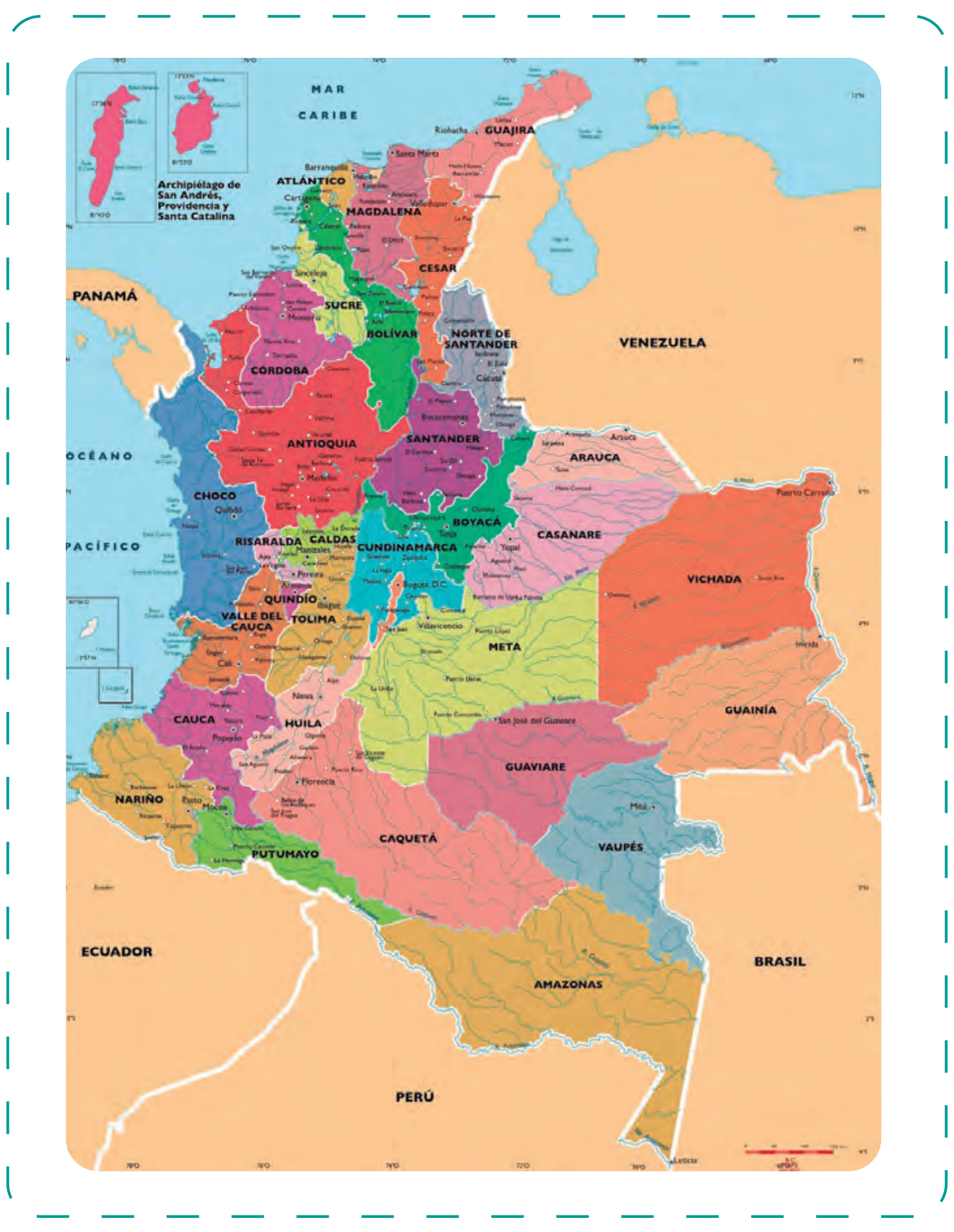




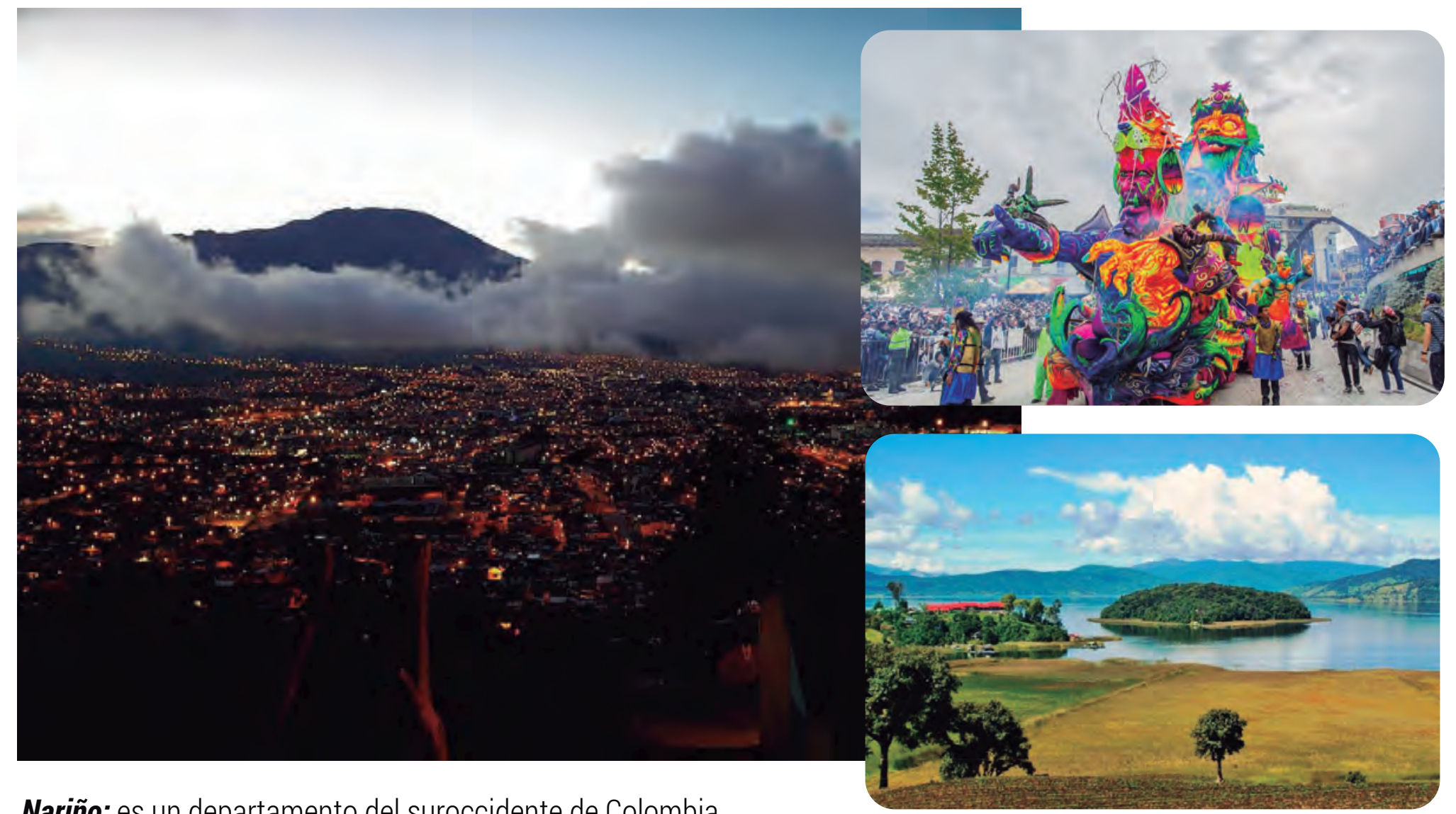

Nariño: es un departamento del suroccidente de Colombia.

Con una geografía determinada por la cordillera de los Andes, su principal actividad es la agricultura. Su capital es Pasto, ciudad localizada en las faldas del volcán Galeras. Su fiesta más importante es el Carnaval de Negros y Blancos que se celebra durante el mes de Enero. Las personas de Nariño suelen denominarse pastusos.

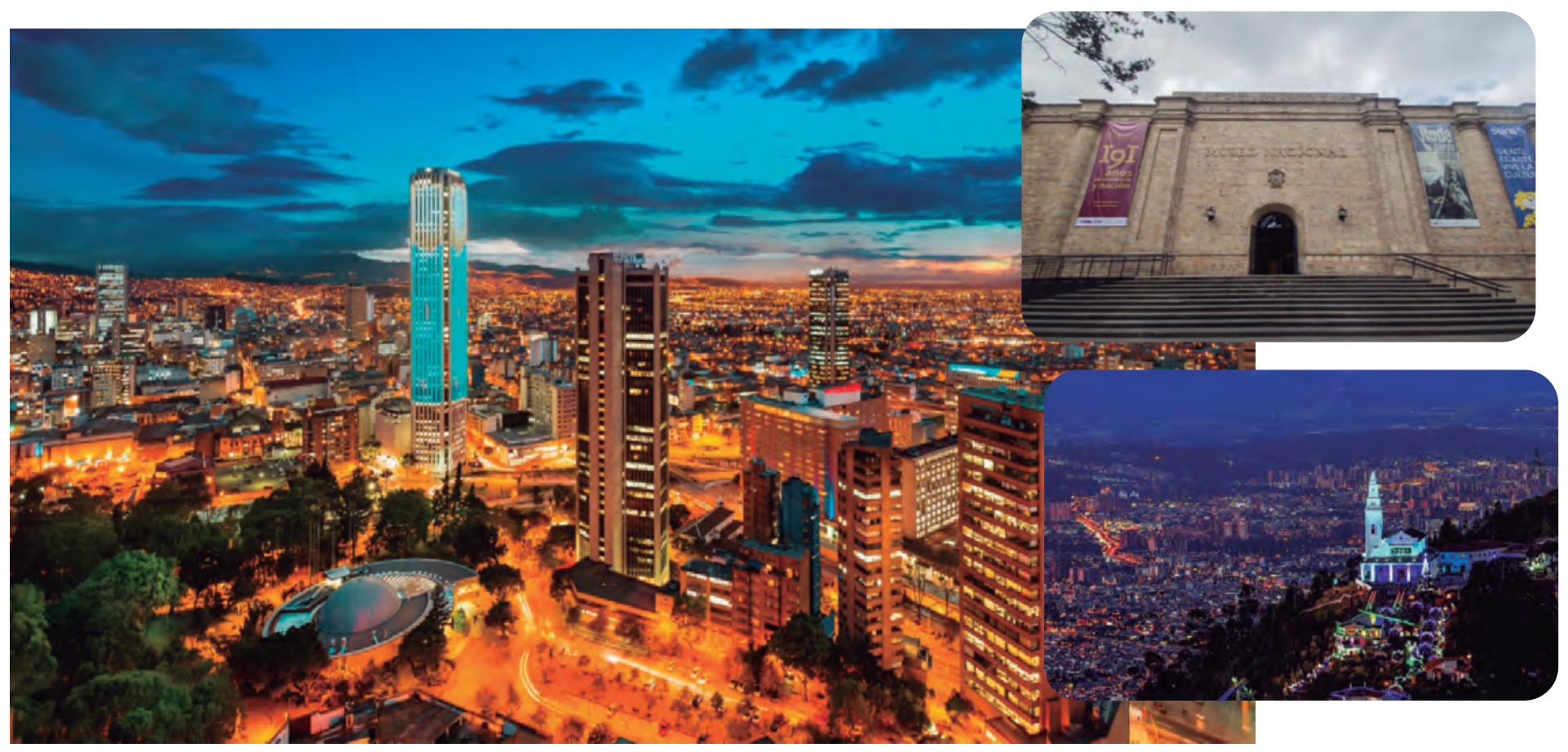

Cundinamarca: es la región del país donde se encuentra la capital, Bogotá, ciudad que reúne personas de todos los lugares de Colombia y en la que se encuentra el Palacio de Bolívar, residencia del presidente de los colombianos. Bogotá es una ciudad moderna y cosmopolita, con un importante desarrollo industrial y cultural. Entre otros atractivos turísticos encontramos el cerro de Monserrate, el Museo Nacional y el Museo del Oro. Las personas de Bogotá suelen denominarse rolos. 


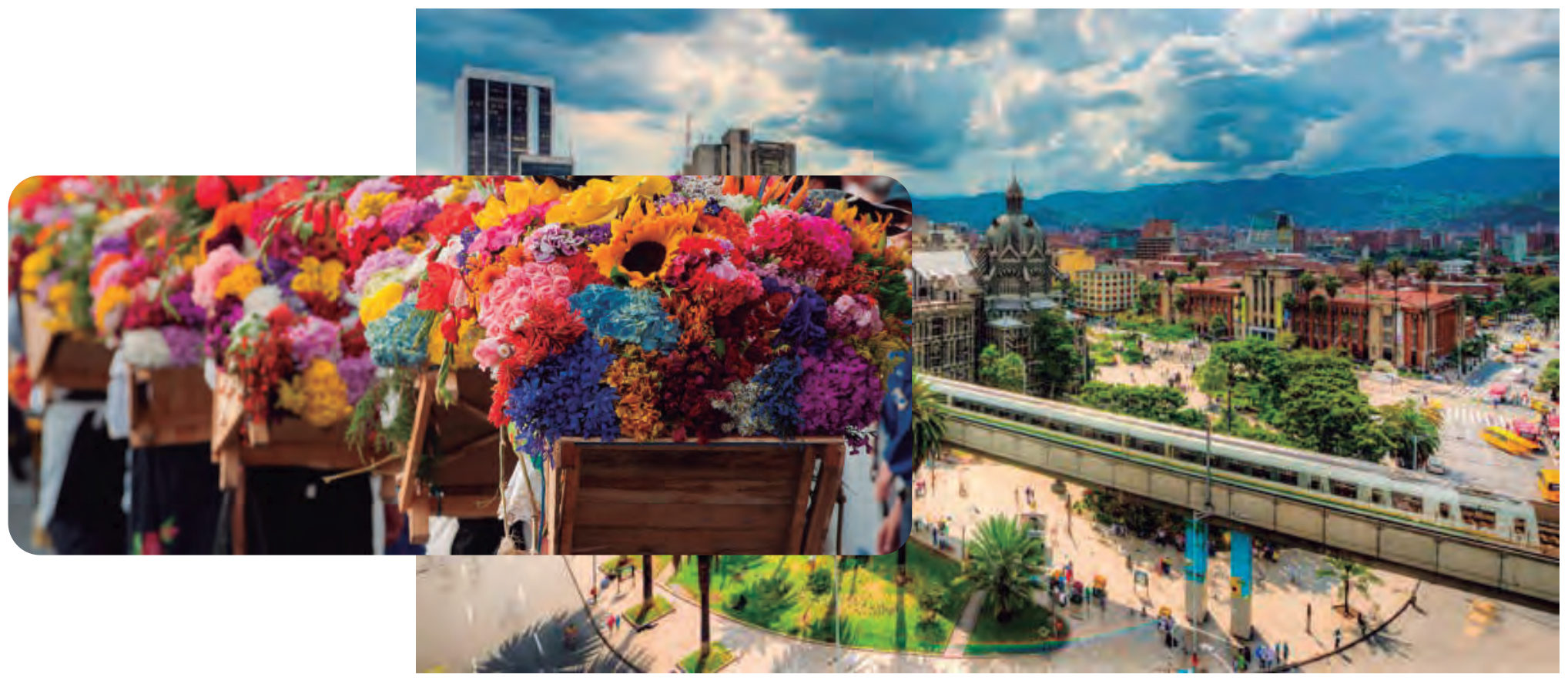

Antioquia: es una de las regiones con mayor desarrollo económico del país. Su capital es Medellín, la segunda ciudad en población e importancia estratégica después de Bogotá; se distingue por su desarrollo urbano e industrial y fue elegida como la ciudad más innovadora del mundo en 2013. Su fiesta más importante es la Feria de las Flores que se celebra en el mes de agosto de cada año. Las personas de Antioquia suelen denominarse paisas.

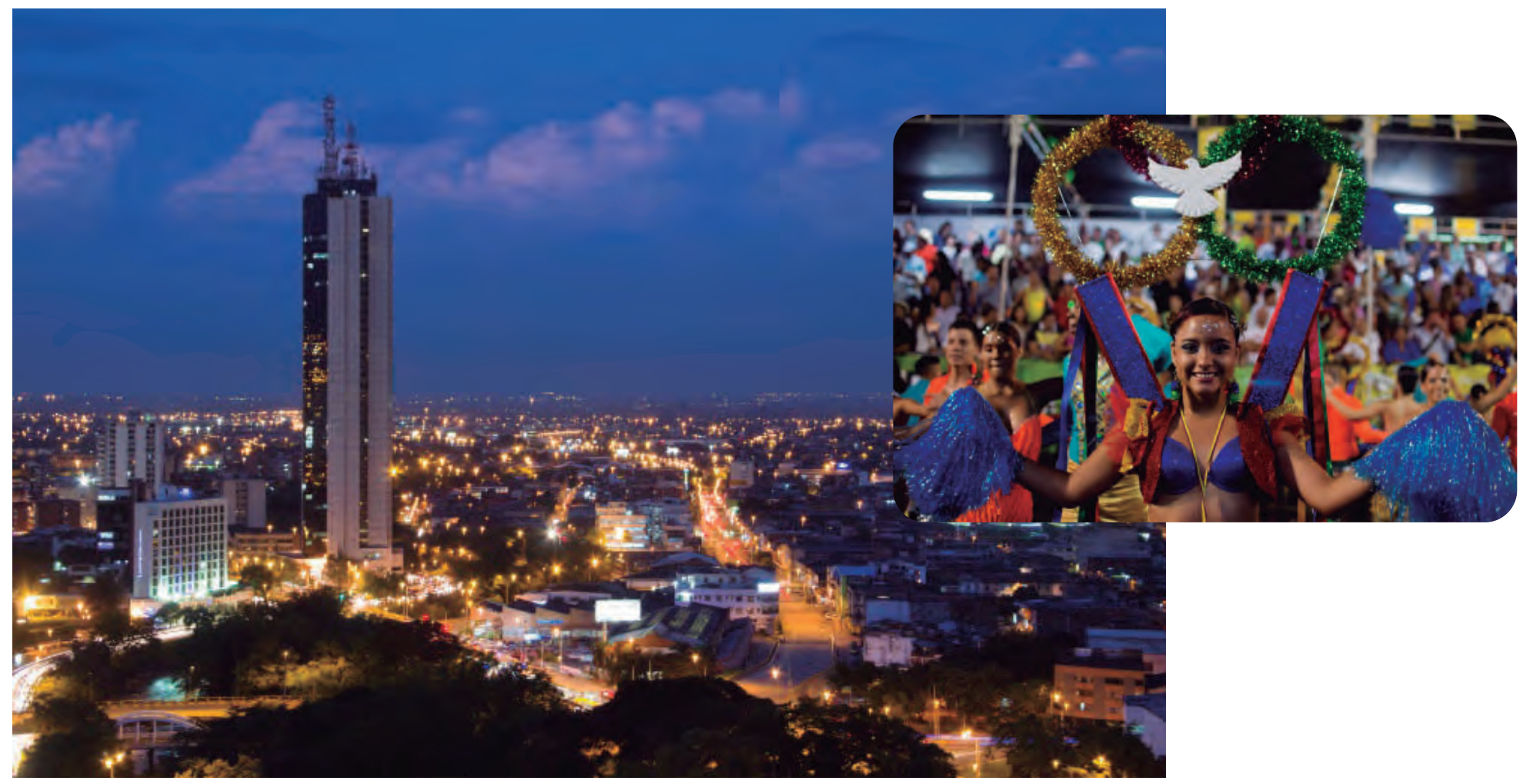

Valle del Cauca: es un departamento del sur de Colombia que se distingue por sus grandes cultivos de caña de azúcar. Su capital es Cali, la tercera ciudad más poblada del país y se distingue no solo por su desarrollo económico, sino también por ser la capital deportiva del país, pues en ella se han celebrado importantes eventos deportivos a nivel internacional. Cali es reconocida por ser la capital mundial de la música salsa y su fiesta más importante es la Feria de Cali que se celebra en el mes de djciembre. Las personas de Cali suelen denominarse caleños. 


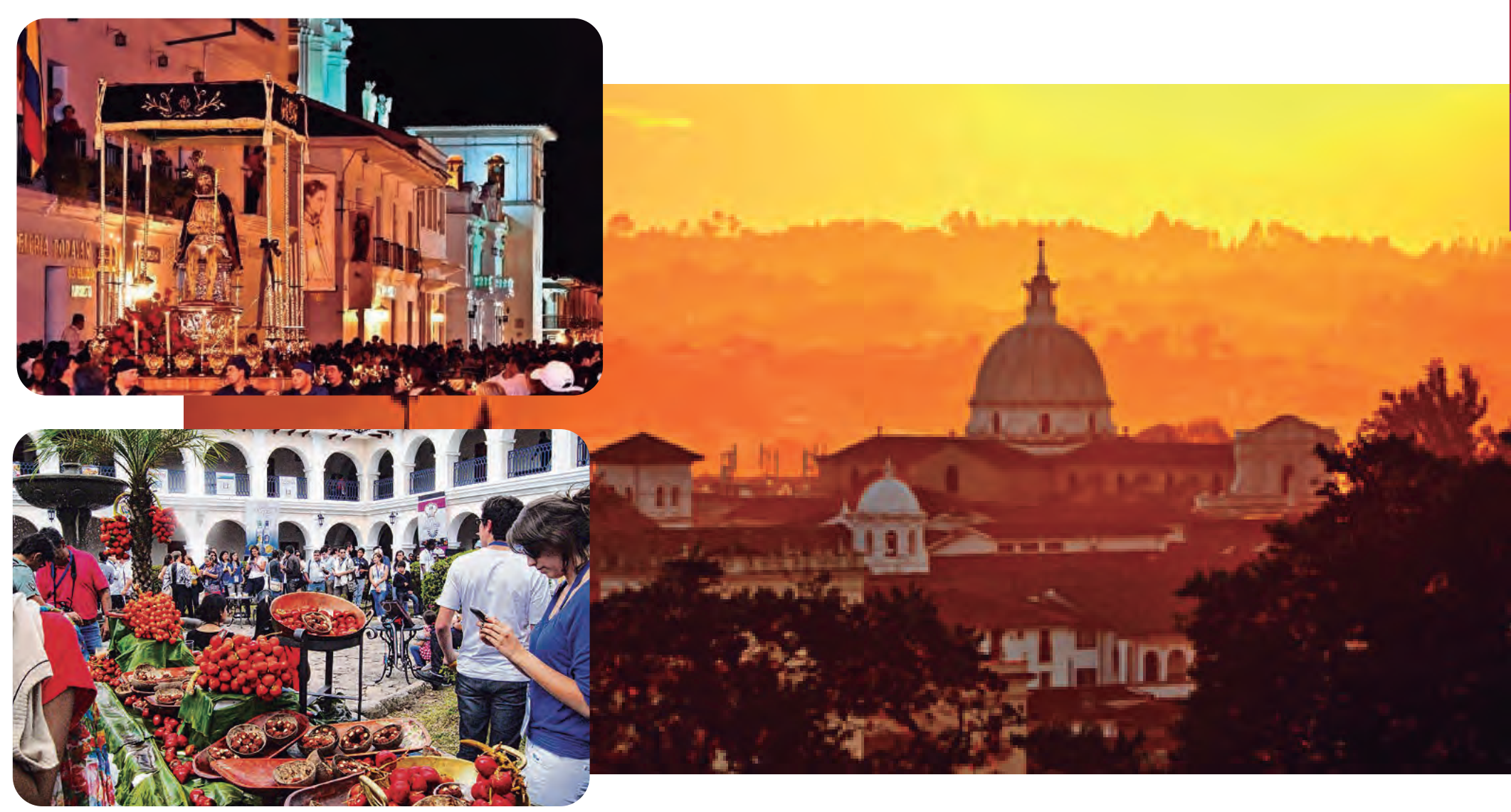

Cauca: departamento del suroccidente cuya capital es Popayán. Esta ciudad se caracteriza por su vida cultural y por ser una ciudad universitaria que alberga gran cantidad de estudiantes de todas las ciudades del país. En ella se celebra anualmente el Festival Gastronómico Internacional y el Festival Internacional de Música Religiosa. Su festividad más importante es la Semana Santa, momento en el que se llevan a cabo las famosas procesiones, consideradas Patrimonio Cultural Inmaterial de la Humanidad. A quienes nacen en Popayán se les llama patojos.

Escoge una región entre las cinco reseñadas, lee atentamente el texto y toma nota en tu cuaderno de la siguiente información:

Capital:

Actividad económica:

Característica principal:

Fiesta más importante:

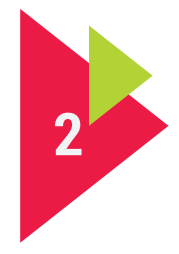

A continuación, en una plenaria de la clase, expón la información del departamento que escogiste. 
3 En parejas, con tu compañero de pupitre, redacta un cuadro informativo acerca del Resguardo de Guambía, similar a los que acabas de leer. No olvides incluir su ubicación, aspectos geográfıcos, actividad económica y festividades importantes. Realiza también un dibujo de alguna de las características antes mencionadas.

Para realizar el ejercicio anterior no olvides tener en cuenta:

Todas las palabras tienen acento (golpe de voz en alguna de sus sílabas), pero no todas llevan tilde o acento gráfico. Las siguientes son las reglas generales para tildar las palabras en español:

- Las palabras que tienen acento en la última sílaba (agudas), llevan tilde cuando terminan en -n, en -s o en vocal. Ej: busqué, león, después.

- Las palabras que tienen acento en la penúltima sílaba (graves o llanas), llevan tilde cuando no terminan en -n, en -s o en vocal. Ej: ángel, azúcar, lápiz.

- Las palabras que tienen acento en la penúltima o en la antepenúltima sílaba (esdrújulas y sobreesdrújulas), llevan tilde siempre. Ej. Sábado, número, cómanselo. 


\section{ESTEREOTIPOS}

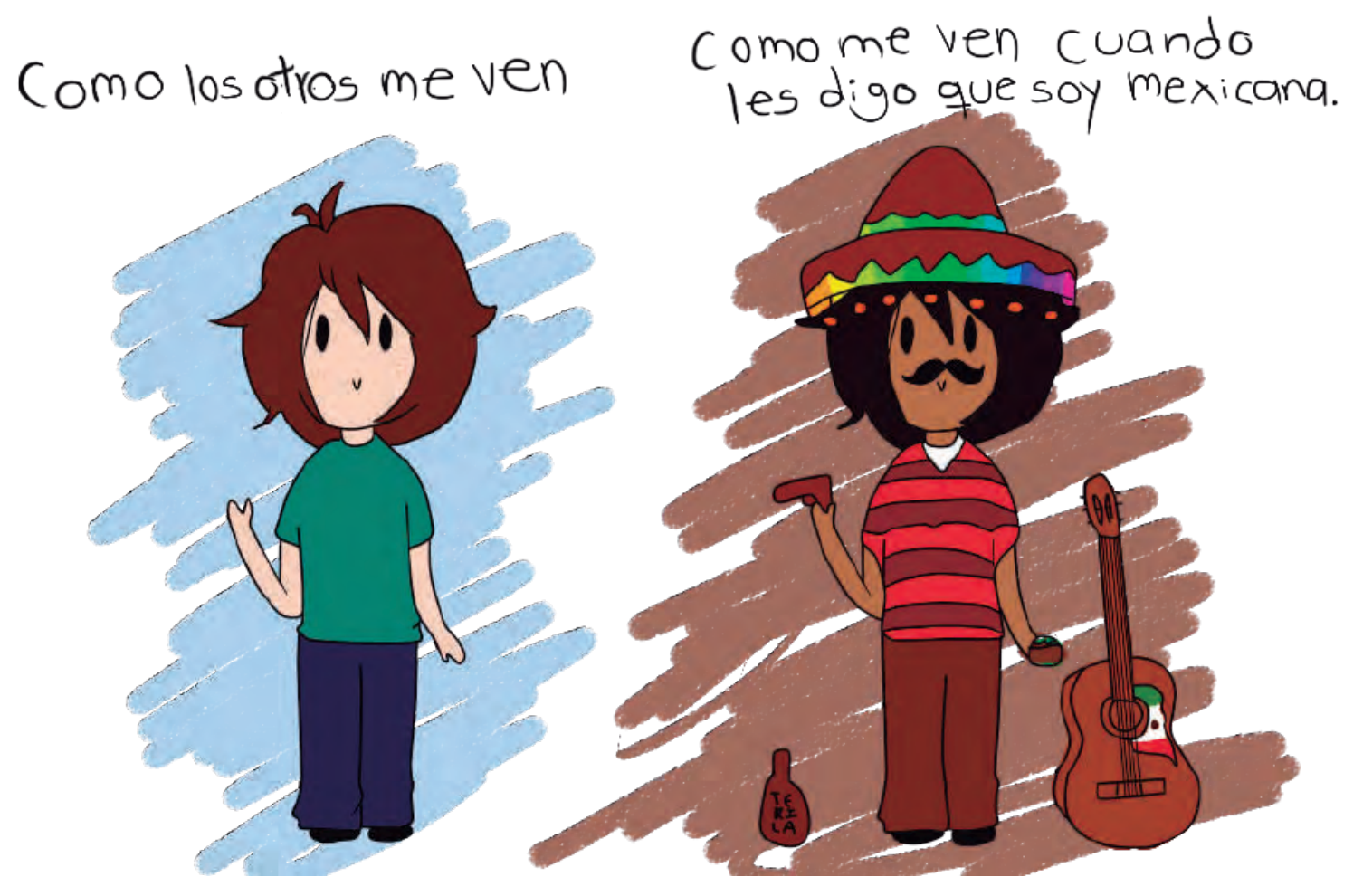

Las personas suelen atribuir diferentes cualidades y defectos a personas pertenecientes a una determinada cultura (país, ciudad, región, resguardo). Estas imágenes o ideas comúnmente aceptadas se denominan estereotipos y no suelen corresponder necesariamente a lo que las personas son realmente. Los estereotipos positivos suelen señalar cualidades mientras que los negativos, defectos.

En Colombia existen diferentes estereotipos respecto a los habitantes de cada una de las regiones del país. A continuación, encontrarás tres estereotipos de cada una de las cinco regiones que acabamos de estudiar. 




\section{Pastuso}

Triste - Poco amistoso

- Serio

\section{Ejemplo}

$\begin{array}{ll}\text { Reservado } & \text { - Mentiroso } \\ & \text { - Tímido }\end{array}$

Regionalista - Amante de lo propio

- Desprecia a los extranjeros

\section{Rolo}

Orgulloso - Seguro de sí mismo

- Cree que los otros son inferiores

Rico - Se apropia de lo ajeno

- Trabajador

Impaciente - Los demás hacen las cosas mal

- Le gusta la eficacia

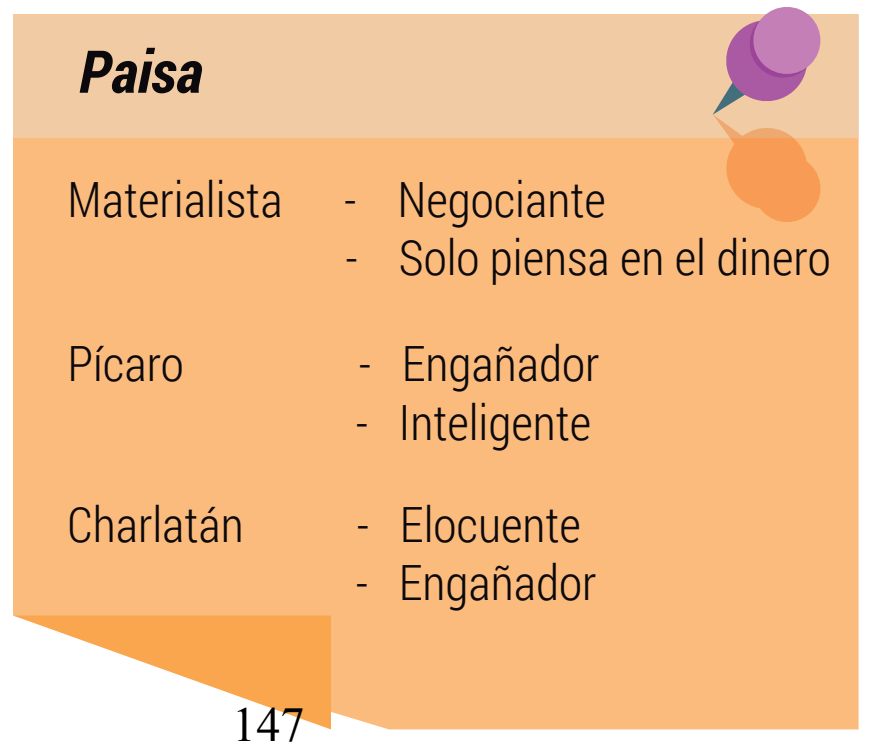




\section{Caleño}

\begin{tabular}{ll}
\hline Ocioso & - Perezoso \\
& - Sabe disfrutar del tiempo libre \\
Rumbero & - Alegre \\
& - Poco serio \\
Lento & - Holgazán \\
& - No tiene prisa \\
\hline
\end{tabular}

\section{Patojo}

Descortés - Grosero

- Directo

Desconfiable - Cauteloso

- Poco claro

Autoritario - Le gusta el orden

- Quiere mandar a los demás

5 Compara tus resultados con los del resto de la clase

\section{EN CASA:}

Escoge otra región del país, diferente a las estudiadas (santandereanos, llaneros, costeños, huilenses, etc.) y escribe un texto en el que describas sus características.

Para redactar este texto ten en cuenta:

Los sustantivos no suelen aparecer solos sino que van acompañados de otras palabras que los modifican y determinan, entre estas palabras encontramos los artículos. Estos anticipan el género y el número del sustantivo y puede ser:

- Definidos (el, la, los, las) que acompañan a personas, animales y cosas que ya conocemos. Ej: El perro de Juan se llama Rino.

- Indefinidos (uno, una, unos, unas) que acompañan personas, animales y cosas que no conocemos. Los padres de Juan le regalaron un perro. 


\section{EN CASA:}

De las cinco estudiadas, escoge la ciudad o región que más llamó tu atención y haz un dibujo que la represente. 


\section{EN CASA:}

Toma un cuento tradicional misak y transfórmalo de modo que lo que sucede se ubique en una ciudad. Puede ser Popayán o Cali u otra ciudad cualquiera que conozcas. Dibuja su respectiva ilustración.

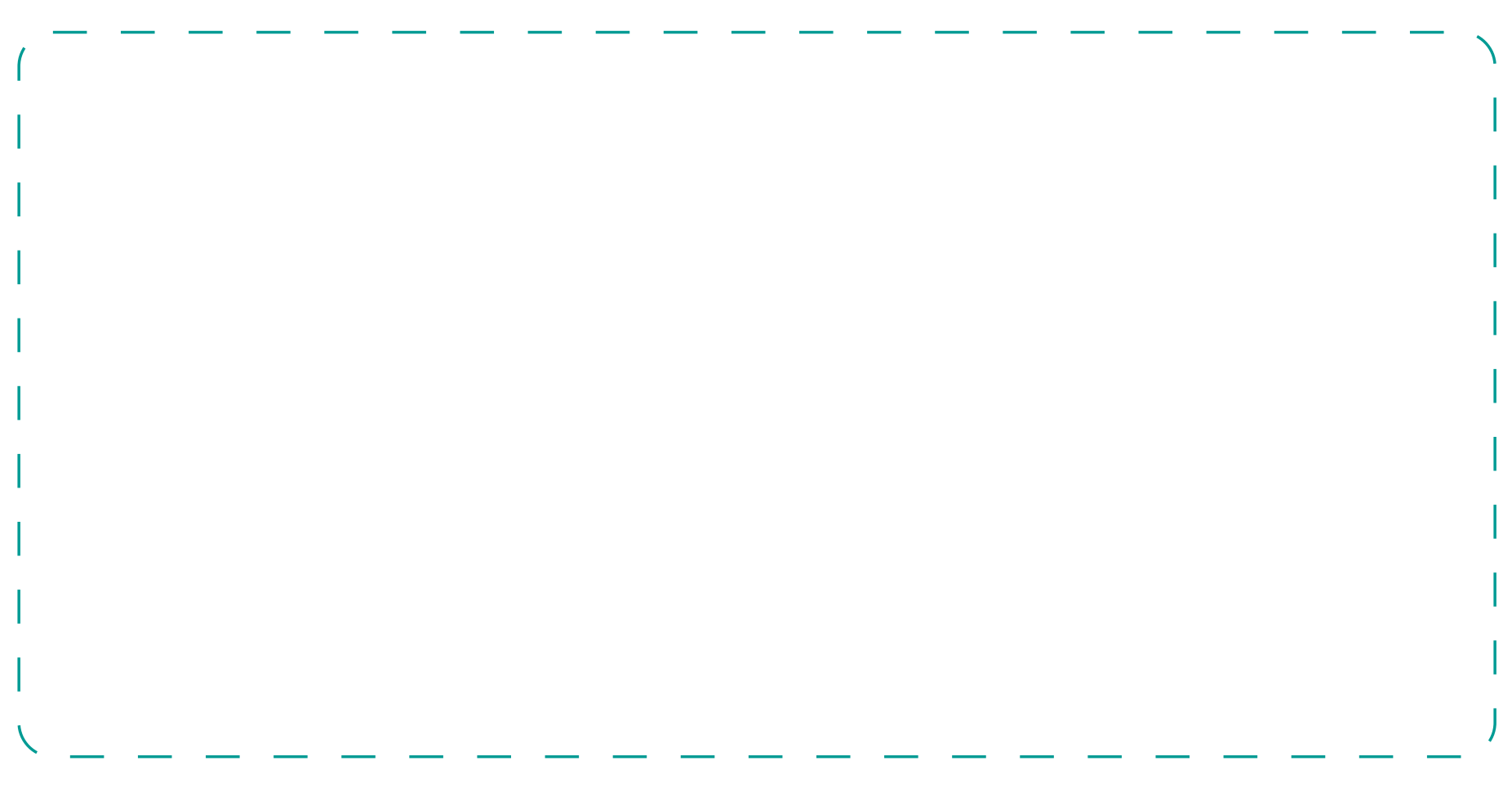

